\title{
WestVirginiaUniversity
}

THE RESEARCH REPOSITORY @ WVU

Graduate Theses, Dissertations, and Problem Reports

2013

\section{Trauma, Memory and Victimhood: Estonia and the Holocaust, 1998-2012}

\author{
Paul Oliver Stocker \\ West Virginia University
}

Follow this and additional works at: https://researchrepository.wvu.edu/etd

\section{Recommended Citation}

Stocker, Paul Oliver, "Trauma, Memory and Victimhood: Estonia and the Holocaust, 1998-2012" (2013). Graduate Theses, Dissertations, and Problem Reports. 258.

https://researchrepository.wvu.edu/etd/258

This Thesis is protected by copyright and/or related rights. It has been brought to you by the The Research Repository @WVU with permission from the rights-holder(s). You are free to use this Thesis in any way that is permitted by the copyright and related rights legislation that applies to your use. For other uses you must obtain permission from the rights-holder(s) directly, unless additional rights are indicated by a Creative Commons license in the record and/ or on the work itself. This Thesis has been accepted for inclusion in WVU Graduate Theses, Dissertations, and Problem Reports collection by an authorized administrator of The Research Repository @ WVU. For more information, please contact researchrepository@mail.wvu.edu. 
Trauma, Memory and Victimhood: Estonia and the Holocaust, 1998-2012

\author{
Paul Oliver Stocker
}

Thesis submitted to the Eberly College of Arts and Science at West Virginia University in partial fulfilment of the requirements for the degree of Master of Arts in History

$$
\begin{gathered}
\text { Robert Blobaum, } \mathrm{PhD}, \text { Chair } \\
\text { Joshua Arthurs, PhD } \\
\text { Elizabeth Fones-Wolf, PhD }
\end{gathered}
$$

Department of History, Morgantown, West Virginia 2013

Keywords: Baltic Studies; East European Studies; European History; Memory Politics; 


\section{ABSTRACT \\ Trauma, Memory and Victimhood: Estonia and the Holocaust, 1998-2012 \\ Paul Oliver Stocker}

Memory of the traumatic Soviet past has both dominated the politics of history in Estonia and been a key determining factor in building a national post-Soviet European identity. As a result, the Holocaust in Estonia has played a less substantial role in both scholarship, and public debate, specifically regarding the nature of local participation in the elimination of Jewish life in Estonia. The subject was catapulted onto the national political agenda in alignment with integration to both NATO and the EU, which clearly viewed Estonia's coming to terms with the event as a matter of importance upon its arrival into the Western community. The lack of discussion over the Holocaust, which had lasted throughout the Soviet occupation and early stages of re-independence, left many Estonians surprised when the nation became the subject of international pressure, and, on occasion, condemnation, for its perceived lethargy or failure to come to terms with this aspect of its uncomfortable past. There now exists a conflict of memory which places the Estonian political elite in a difficult position in terms of reconciling their nation's victimhood status and the demands of the international community, which seeks an honest and open discussion about the meaning of the Holocaust in Estonia. This paper will highlight and analyse this conflict through a study of political memory found in speeches, commemorations and the museums of Estonia, which demonstrate how contemporary historical narratives are being represented, shaped and constructed. The debate surrounding memory of the Holocaust and coming to terms with both Nazi and Soviet occupations and their respective crimes is not unique to Estonia. Thus, the implications of this study extend further than national borders and should be seen firmly within their Central-East European context. 
Table of Contents

INTRODUCTION

1

CHAPTER ONE: HISTORICAL BACKGROUND 6

CHAPTER TWO: LITERATURE REVIEW

11

2.1 Holocaust Memory in EAST-CENTRAL EUROPE

11

2.2 The Estonian MEMORY NARRATIVE AND VictimHood

CHAPTER THREE: THEORY \& METHODOLOGY

3.1 DEFINING POLITICAL MEMORY

3.2 INTERNATIONAL AND TRANSNATIONAL MEMORY

3.3 DOMESTIC MEMORY

3.4 METHODOLOGY

38

CHAPTER FOUR: ESTONIAN HOLOCAUST MEMORY IN ITS INTERNATIONAL CONTEXT

4.1 SUPRANATIONAL HOLOCAUST MEMORY 40

4.2 INTERNATIONAL AND TRANSNATIONAL INTERVENTION

CHAPTER FIVE: ESTONIAN DOMESTIC HOLOCAUST MEMORY 55

5.1 HOLOCAUST COMMEMORATIONS AND SPEECHES IN ESTONIA 55

5.2 ESTONIAN MUSEUMS AND THE HOLOCAUST 65

CONCLUSION 79

BIBLIOGRAPHY 85

PRIMARY SOURCES 85

SECONDARY SOURCES 87 


\section{INTRODUCTION}

The trauma experienced by Estonia during World War Two left an indelible mark on the small Baltic state, and one which the subsequent five-decade long Soviet occupation would only exacerbate. The two Soviet occupations (1940-1941 \& 19441991) being the longest, most brutal to the Estonians and freshest in the public mind have, not without reason, been given prominent attention in both scholarship and public debate. The short, but nevertheless brutal German occupation has been subject to less attention. This is particularly true about the Holocaust on Estonian soil. The event itself, both during and after, did not interact with the majority of the Estonian public as it was small in scale and located in remote concentration and labour camps. The issue was repressed under the Soviet occupation and remained on the periphery of the public and scholarly agenda after re-independence until the formal process of NATO and EU accession began in 1998.

The Holocaust subsequently began to attract more attention, particularly in educational spheres instigated almost entirely by foreign pressure. Western-led institutions, defined in this thesis by both the EU and NATO, ${ }^{1}$ considered it imperative that Estonia come to terms with the Holocaust as part of their long-term goal of Western integration. Following NATO and EU accession, the Estonian political elite has sought to address the issue of the Holocaust whilst also maintaining the nation's victimhood status. At times, commemorations of the Holocaust have been used to draw the international community's attention to the historical plight of Estonians and to gain support in condemning Soviet crimes. What is clear is that the politics of history in Estonia, which has dominated political affairs since re-independence, gained a new

\footnotetext{
${ }^{1}$ Both institutions interact with Estonia differently in relation to Holocaust memory. This is discussed in greater depth at the beginning of section 4.2.
} 
dimension when it joined the European community in 2004. The Holocaust has added to an increasingly complex commemoration culture which can be witnessed at both a domestic and international level.

In the wake of an increase in globalisation and European integration, scholars of memory are becoming increasingly aware of the need to broaden the scope of study beyond national borders. Memory is becoming less and less the product of national political elites, and subject to wider regional and global collective memories which are institutionalised in supranational organisations such as the European Union. The Holocaust has been interpreted by several scholars as one of the world's truly 'global' collective memories. ${ }^{2}$ There is a growing intercontinental view of the Holocaust as the measuring stick of human morality and the foundation of modern human rights understanding. The Holocaust has been interpreted by some as the 'foundational myth' of Europe ${ }^{3}$ and a reason in itself for Europe to integrate so as to never descend to such barbarity ever again. The issue with these global interpretations is that many countries, particularly many European post-Communist states, do not subscribe to the 'foundational myth' thesis. Different historical experiences, particularly of Soviet crimes, as well as different philosophical interpretations of European integration have led many to question, often in controversial fashion, why the Holocaust should take a leading role in crimes against humanity.

It is within this latter group that the small Baltic state of Estonia finds itself. Annexed by the Soviet Union in 1940, Estonia suffered Stalin's wrath before a shot was fired in Western Europe. Estonia was occupied by Nazi Germany from July 1941 to the

\footnotetext{
${ }^{2}$ Daniel Levy and Natan Sznaider, Holocaust And Memory In The Global Age, trans. Assenka Oksiloff, 1st ed. (Temple University Press, 2005).

${ }^{3}$ Dan Diner, "Restitution and Memory: The Holocaust in European Political Cultures," New German Critique no. 90 (2003): 36.
} 
fall of 1944, a result of which would see the near-total eradication of Estonian Jewry and Jewish culture, leading to Estonia being declared the first Nazi territory to be Judenfrei at the Wannsee Conference in 1942. The Soviet Union would re-occupy Estonia once again in 1944, an occupation which would last until 1991. Estonia would be unable to confront its role in the Holocaust as a national entity until re-independence, and it is the period and process of re-independent Estonia coming to terms with its own role in the Holocaust which frames this study. Estonia makes for an exceptionally interesting case study for a number of reasons. First, given that the Holocaust was on a smaller scale and less public than in other East European states, memory and coming to terms with the past can be seen as different in its nature, whilst also maintain several contextual continuities; most importantly the issue of 'double victimhood'. Estonia is also significant in terms of how Holocaust memory has been predominantly generated from outside its borders as a result of Western integration and directly a product of the political elite rather than the public. This demonstrates that memory of the Holocaust in Estonia is an elite-driven enterprise, representing a considerable fracture with the public's memory of the Holocaust, which is relatively scarce.

There is a significant gap in the literature with regard to the role of the Holocaust in contemporary Estonian memory. Works by Pettai and Stevick have both looked at education and historiography of the Holocaust in Estonia as 'sites of memory' and as important factors in how the Holocaust is represented in the present day. Both studies also allude to the role of international forces in the shaping of Holocaust memory and their role in bringing the Holocaust onto the national agenda. They therefore provide this study with a good foundation upon which to build. This study will analyse two further sites of memory: political commemorations and museums. It also 
builds on the work of Pettai and Stevick by placing the case of Estonian Holocaust memory within an international context, and analysing the role of other states, intergovernmental and supranational institutions and non-governmental organisations within Estonian memory narrative construction. Anton Weiss-Wendt also looks at the role of history commissions and the Simon Wiesenthal Centre and uses an analysis of web-based internet discussion forums to discover whether anti-Semitic stereotypes of 'Judeo-Bolshevism' are present in Estonia. However, Weiss-Wendt's conclusions are based on serious methodological weaknesses, and thus this study will be using a different methodology that is more useful in understanding 'why the holocaust doesn't matter to Estonians' or indeed whether this bold statement is true. Ultimately, by analysing the influence of international actors as well as domestic Estonian memory politics through a critical analysis of commemorations and museums between 2005 and 2012, this study seeks to go further than others and contribute to the relative dearth of literature.

Several broad research questions will guide this study, the most important being; how and why was the Holocaust brought onto the Estonian national agenda by the international community? How has the political elite subsequently looked to balance the demands of both the public and international community in constructing a narrative of the Holocaust in Estonia?

The methodological structure of this thesis will utilise two analytical dimensions in order to fully elucidate the nature of Holocaust memory in Estonia: international and domestic. Contemporary scholarship on Holocaust memory emphasises the role of the Holocaust in international relations. The international dimension will focus on how forces from outside Estonia have looked to influence Estonian memory of the 
Holocaust. When looking at the role of international organisations, information and data will be taken from publications of supranational organisations, from state and non-state actors, as well as from any secondary sources which will help provide context. The domestic dimension will focus on how elite politicians of Estonia have attempted to incorporate the Holocaust into the broader memory politics of the nation through an analysis of their speeches. An analysis of museums in Estonia, which are also indicative of constructed collective memory, will also be conducted to show how the Holocaust is represented in the domestic dimension.

Despite this study going further and deeper in its analysis than other works on Estonian Holocaust memory, several limitations remain. As it will deal with elite constructions of memory, their interaction with the Estonian public will not be addressed. Understanding public opinion of the Holocaust would provide a fairly comprehensive answer to the question of Holocaust memory in contemporary Estonia. However, the time and financial constraints that would be incurred by a full-scale survey analysis have placed this matter beyond the scope of this thesis. Another limitation for this study is the author's lack of Estonian language skills. However, all the relevant and key secondary and primary texts are available in English, to make a more narrowly focused examination possible. 


\section{CHAPTER ONE: HistoricAl BACKGROUND}

It is important that, before an analysis of Holocaust memory is undertaken, a brief overview of the events of the Holocaust within Estonia during 1941-1944 is presented. In particular, it is important, to highlight those features that differentiate Estonia from other Nazi-occupied territories where local collaboration was prevalent. The Holocaust and interwar Jewish relations were relatively unique in Estonia in comparison with other Central-Eastern European nations.

The Holocaust in Estonia led to the complete eradication of Jewish life in Estonia, which began in the $19^{\text {th }}$ century following permission for permanent Jewish settlement granted by Tsar Nicholas II. The Jews of Estonia would thrive in what was a tolerant society until the Molotov-Ribbentrop Pact in August 1939. The Soviet Union's annexation of Estonia in 1940 would mark the beginning of nearly fifty years of occupation, and Estonians would feel the wrath of Stalin's terror almost immediately. Estonian society was decapitated by the arrest of 47,000 Estonians for political reasons, 35,000 of whom would be deported (including $10 \%$ of the local Jewish population) to the Soviet interior and labour camps. In addition, 34,000 were conscripted into the Red Army in 1941, of which around a third perished. ${ }^{4}$

Following Operation Barbarossa, the Nazi assault on the Soviet Union led to 3,000 of the approximate 4,000 Estonian Jews to pre-emptively flee eastward. ${ }^{5} 963$ Estonian Jews were killed during the subsequent German occupation, leading to Estonia

\footnotetext{
${ }^{4}$ Olaf Mertelsmann and Aigi Rahi-Tamm, "Soviet Mass Violence in Estonia Revisited," Journal of Genocide Research 11, no. 2-3 (2009): 323.

5 There were approximately 4,400 Jews living in Estonia in 1934, however, the Soviet deportations in 1941 led to approximately 400 being deported to the Gulag labour camp system.
} 
becoming the first Nazi territory to be declared Judenfrei (free of Jews). ${ }^{6}$ The massacre did not stop with local Jewish inhabitants. The 22 concentration and labour camps erected would be the destination of the vast majority of the 7,651 European Jews who were killed in Estonia during the occupation (largely from Lithuania, Latvia and Czechoslovakia). ${ }^{7}$ Local cooperation was essential for the occupation administration to carry out the atrocities, and many Estonians collaborated with the Self-Administration, Security Police, Omakaitse (home guard) and also fought with the $20^{\text {th }}$ Waffen SS Division. Estonian forces would re-establish national sovereignty for a matter of days in 1944, before they were crushed by the Red Army, re-establishing Soviet power.

The extent and character of local collaboration remains the subject of debate amongst historians. The Estonian group within the German Security Police was given unprecedented autonomy by the German authorities, who left most decision-making to the Estonians. Jews were arrested in Tallinn, Parnu, Viljandi and Tartu by the autonomous security forces and were the victims of executions by the Omakaitse. Jewish women and children were also rounded up and deported to makeshift camps. In 1942, when Jews arrived from other parts of East-Central Europe, they were sent to labour camps overseen and operated by Germans and some Estonians. The liquidation of the Klooga concentration camp was also conducted by Estonians in units of the $20^{\text {th }}$ Waffen SS Division under German orders, and saw the killing of approximately 2,000 prisoners. $^{8}$ The reasons for collaboration remain unclear, and the tradition of good

\footnotetext{
${ }^{6}$ The Holocaust in Estonia was considerably smaller in scale than in other East-Central European occupied states, including the other two Baltic States. Approximately 70,000 Latvian and 195,000 Lithuanian Jews would be killed.

${ }^{7}$ Toomas Hiio, Meelis Maripuu, and Indrek Paavle, eds., Estonia 1940-1945: Reports of the Estonian International Commission for the Investigation of Crimes Against Humanity (Estonian Foundation for the Investigation of Crimes..., 2005), 758.

${ }^{8}$ Birn, "Collaboration with Nazi Germany in Eastern Europe: The Case of the Estonian Security Police," Contemporary European History 10, no. 02 (2001): 191.
} 
Estonian-Jewish relations before the war only complicates matters. Many Estonians actively disagreed with the Nazi treatment of Jews, and there are several cases of locals trying to save Jews. ${ }^{9}$ Birn finds most purchase in the idea that many collaborators linked the Jewish threat purported by Nazi propaganda to the Bolshevik threat. ${ }^{10}$ WeissWendt's analysis of Estonian collaboration differs. He claims that Estonians, who were suffering from a kind of post-traumatic stress disorder following the brutal Soviet occupation, took Nazi promises of independence and autonomy seriously. Germany harnessed anti-Soviet feelings and Estonian nationalism effectively, and it was within this confusion that Estonians co-operated in the Holocaust. ${ }^{11}$ Weiss-Wendt's conclusions have been met with considerable scrutiny and criticism by many in Estonia, two examples being a particularly unfavourable in national newspaper Eesti Ekspress ${ }^{12}$ and a more balanced, but nevertheless critical review by Historian Dr Olaf Mertelsmann. ${ }^{13}$

As stated before, very little has been published on the Holocaust in Estonia. 'Murder Without Hatred' is the most recent, and most comprehensive book on the Holocaust in Estonia and was published by Syracuse University Press, New York, in English only. ${ }^{14}$ The book generated much scholarly debate about its findings and conclusions, as discussed above. However, the book clearly breached the scholarly sphere and to a certain level, was debated amongst the public. Eesti Ekspress published

\footnotetext{
${ }^{9}$ Ibid., 187-191.

${ }^{10}$ Ibid., 188.

${ }^{11}$ Anton Weiss-Wendt, Murder Without Hatred: Estonians and the Holocaust, 1st ed, Religion, Theology, and the Holocaust (Syracuse, N.Y: Syracuse University Press, 2009), 330-345.

12 "Narvast Pärit Ajaloolane: Eestlastel Puudub Inimlikkus," Ekspress, accessed April 22, 2013, http://www.ekspress.ee/news/paevauudised/ajalugu/narvast-parit-ajaloolane-eestlastel-puudubinimlikkus.d?id=28787571.

${ }^{13}$ Olaf Mertelsmann, "Mõrv Ilma Vihata. Eestlased Ja Holokaust," Sirp: Eesti Kultuurileht, October 23, 2009.

${ }^{14}$ The History Commission findings, which Weiss-Wendt includes, also provide a comprehensive overview of the Holocaust in Estonia. However, the report cannot really be considered as a scholarly book and is purely fact-finding, as opposed to Murder Without Hatred.
} 
a particularly unfavourable review of the book, and Pekka Erelt completely rejected Weiss-Wendt's conclusions, describing the book as "not exactly a historical study but a useless propaganda book that incites hatred". ${ }^{15}$ The review was clearly being written in light of Western criticism of Estonia. It was clearly also responding to condemnation from the Russian Federation, who had previously criticised Estonia following the public reunions of Estonian veterans who fought in the Waffen $\mathrm{SS},{ }^{16}$ stating that, "This book gives currency to the deliberate myth of the $21^{\text {st }}$ Century that portrays Estonians as cruel nation for which humanity is a foreign word-the nasty little nation whose state is an annoying relic. ${ }^{, 17}$ Interestingly, Erelt also made several thinly-veiled digs at WeissWendt's background from Narva; a predominantly Russian area of Estonia. ${ }^{18}$

Weiss-Wendt has also been the victim of dozens of offensive and anti-Semitic messages from members of the Estonian public, who criticised the book, principally on grounds unrelated to its methodology or content. The messages ranged from crude antiSemitism which attack Weiss-Wendt's ethnicity to others accusing him of being an agent of the Russian Federation. ${ }^{19}$ One would be completely foolish to speculate that the opinions of a few fanatics are representative of a national problem. What this small but vociferous reaction to Weiss-Wendt's book represents is not so much a Jedwabne-style debate, but rather an indication of the unwillingness of some in the public and media to view the Second World War outside of a narrative of victimhood and the reluctance to engage in the debate which was sparked by Estonia's integration into the West. One can

\footnotetext{
15 “Narvast Pärit Ajaloolane: Eestlastel Puudub Inimlikkus,” Ekspress, accessed April 22, 2013 , http://www.ekspress.ee/news/paevauudised/ajalugu/narvast-parit-ajaloolane-eestlastel-puudubinimlikkus.d?id=28787571.

16 "Russia Condemns Estonian SS Legion Reunion - 1," RIA Novosti, accessed May 21, 2013, http://en.rian.ru/russia/20070730/69960232.html.

${ }^{17}$ Ibid.

18 Ibid.

${ }^{19}$ Evidence for this was obtained through private correspondence with Anton Weiss-Wendt, who very kindly sent several pages of the hate-messages he received following the Eesti Ekspress review.
} 
only speculate the intense reaction the book may have received if it were published in Estonian, not English.

To reiterate: the Holocaust and nature of local collaboration in Estonia were very different from other Nazi-occupied territories, particularly neighbouring Latvia and Lithuania, and thus should not be illogically lumped together with other East-Central European states under Nazi occupation. It is worth noting at this point that whilst this study views Estonia's coming to terms with the past as fully within its East European context, the historical actualities of the Holocaust remain extremely diverse. The Holocaust was conducted less publicly and on a much smaller scale in Estonia than other Nazi-occupied territories. There were also no pogroms or ghettos like in Lithuania or Latvia. Collaborators cannot all be simply labelled as mass-murderers, and many had relatively passive roles in the guarding of labour camps, while the liquidation of camps such as Klooga was executed by local forces under strict German orders. However, the process of top-down Vergangenheitsbewaltigung (coming to terms with the past) in Estonia following the collapse of the Soviet Union is relatively similar in both its elite and transnational nature and can be placed within the East-European context despite differences in how the Holocaust was conducted and the extent of local collaboration. This allows the case of Estonia to be discussed within the context of East European post-Communist nations seeking European integration and coming to terms with a traumatic past. All such nations had to deal with troublesome historical events such as the Nazi past following decades of oppression and a period when the Holocaust was minimalized as an event. Estonia, like other post-Communist EU member states have also suffered from the dilemma of how to remember two totalitarian occupations which both led to indelible stains on national histories. 


\section{CHAPTER TWO: LITERATURE REVIEW}

The literature review will look to analyse key scholarly works relating to the subject of Holocaust memory in Estonia. In order to frame Estonian memory of the Holocaust, it is first necessary to present key works which examine the broad research problem that this study will address: Holocaust memory in post-Communist EastEuropean nations seeking Western integration. The literature on Holocaust memory in East-Central Europe will highlight an issue relevant to both Estonia and to other nations in the region, which is the presence of a 'rivalry in victimhood', witnessed in postCommunist nations which suffered at the hands of both the Soviet Union and Nazi Germany. This will lead to a discussion of victimhood in Estonian memory, and the prevalence of the crimes of the Soviet Union in contemporary memory which is an issue which relates directly to Holocaust memory.

\subsection{Holocaust Memory in East-Central Europe}

The scholarly literature on the Holocaust in post-Communist European nations seeking Western integration has largely emerged since the turn of the $21^{\text {st }}$ century in advance of the ten former Communist states' accession to the European Union. However, studies are often fragmented into regions, nations and specific sites of memory that fall short of a comprehensive analysis of collective memory. This section will aim to piece together works on the various lieux de mémoire ${ }^{20}$ of East-Central Europe which reflect an embedded understanding of the Holocaust and its interaction with national memory. Works on Holocaust memory in East-Central Europe will be

\footnotetext{
${ }^{20}$ Pierre Nora, "Between Memory and History: Les Lieux de Mémoire," Representations no. 26 (April 1989): 7-24.
} 
analysed for several reasons. Firstly, due to the lack of literature specifically relating to Estonian Holocaust memory it is important to look at similar studies of different countries in order to draw on the methods used by the authors. Secondly, whilst this study recognises the historical differences between the Holocaust in Estonia and other East-Central European states, the process of coming to terms with the past is fundamentally similar at an elite political level. Furthermore, all Central-East European states, Estonia included, find themselves on the same side of the debate over European memory politics as they were all subject to Nazi and Soviet occupations. They therefore can and should be looked at with this contemporary debate in mind.

Much scholarly debate over the Holocaust and its representation in contemporary society focuses on the question of who the originators and constructors of collective memory narratives are. There is an increasing consensus that public memory, even in democracies, is almost always 'top-down'. Eric Langenbacher, in a comparative study of collective memory in Poland and Germany, argues that 'memory regimes' are almost always elitist and top-down communications from politicians and intellectuals. Whether or not the public accept these elitist versions of history is a different matter. Yet, according to Langenbacher their origin is practically always from the upper echelons of society. ${ }^{21}$ Shafir, in his seminal work on Holocaust memory in East-Central Europe, locates the origin of memory as coming largely from the political elite in an attempt to both construct memory and reflect public opinion. ${ }^{22}$ Dan Diner boldly equates the Holocaust and its role as the foundational myth of Europe as comparable to

\footnotetext{
${ }^{21}$ Eric Langenbacher, "Twenty-first Century Memory Regimes in Germany and Poland An Analysis of Elite Discourses and Public Opinion," German Politics \& Society 26, no. 4 (Winter 2008): 50-55; EvaClarita Onken, "The Baltic States and Moscow's 9 May Commemoration: Analysing Memory Politics in Europe," Europe-Asia Studies 59, no. 1 (2007): 23-46.

${ }^{22}$ Michael Shafir, Between Denial and "Comparative Trivialization": Holocaust Negationism in Postcommunist East Central Europe (Hebrew University of Jerusalem, Vidal Sassoon International Center for the Study of Antisemitism, 2002).
} 
the Reformation or French Revolution "to which historical memory, as it thickens into a catalogue of narrations and values, seems to lead back". ${ }^{23}$ Diner's analysis sees memory again as a construction from above. The growth of globalism and role of supranational institutions, particularly in Europe, has added a dimension to the ways in which memory regimes are constructed and imposed upon the public. Particularly in the context of Estonia, scholars have argued that international forces such as NGOs have either explicitly or implicitly attempted to construct, manipulate and above all, influence the narratives of Holocaust memory within nation states. ${ }^{24}$ Others have highlighted the influence supranational organisations such as NATO and the EU have on pressuring countries to confront 'awkward' national memories and commemorative practices. ${ }^{25}$

If Holocaust memory is constructed by elites, how and where is it presented to the public? The locations of Holocaust memory have been presented in various 'lieux de mémoire' (sites of memory) across East-Central Europe. Jeffrey Blutinger shares many of Shafir's concepts and depiction of the structures of top-down memory. Blutinger also analyses Museums in Eastern Europe in an attempt to understand how elite discourses of memory are represented and interact with the public. Blutinger neglects the opportunity to determine whether or not the public 'buys' the narratives presented by museums; however, his work represents a positive contribution to the sites where

\footnotetext{
${ }^{23}$ Diner, "Restitution and Memory," 36.

${ }^{24}$ Onken, "The Baltic States and Moscow's 9 May Commemoration"; E. Doyle Stevick, "Education Policy as Normative Discourse and Negotiated Meanings: Engaging the Holocaust in Estonia," PROSPECTS 40, no. 2 (June 1, 2010): 239-256; Benoît Challand, "1989, Contested Memories and the Shifting Cognitive Maps of Europe," European Journal of Social Theory 12, no. 3 (August 1, 2009): 397-408; Maria Mälksoo, "The Memory Politics of Becoming European: The East European Subalterns and the Collective Memory of Europe," European Journal of International Relations 15, no. 4 (2009): 653-680; Anton Weiss-Wendt, "Why the Holocaust Does Not Matter to Estonians," Journal of Baltic Studies 39, no. 4 (2008).

${ }^{25}$ Stevick, "Education Policy as Normative Discourse and Negotiated Meanings."
} 
memory has been transmitted from the political elite to the public. ${ }^{26}$ The most popular method of analysing Holocaust memory, particularly since Jan Tomasz Gross' controversial book 'Neighbours: The Destruction of the Jewish Community in Jedwabne, Poland', ${ }^{27}$ has been through a qualitative analysis of historiographical and scholarly trends.

Scholarship, which includes academic and intellectual works and historiographical interpretations of the Holocaust, is another example of a lieux de memoire and demonstrates a direct way in which intellectuals and political elites can attempt to influence the public's memory. Several scholars have argued that each Baltic State's use of International History Commissions, which began in $1998,{ }^{28}$ represents an attempt to create a degree of consensus on the factual debates of the Holocaust. ${ }^{29}$ This differed from previous years, where factual analysis and historical interpretations were debated fiercely in some cases, or not explored deeply enough, particularly in Estonia. Weiss-Wendt's analysis of the lack of scholarly debate in Estonia on the Holocaust in comparison with other East-Central European states provides an indication that memory that is rooted in historical interpretations requires academic debate to contribute to public knowledge. He shows scholarly analysis of the Holocaust in Estonia to be much like the public's attitude: indifferent to an open examination and focused on the

\footnotetext{
${ }^{26}$ Jeffrey Blutinger, “An Inconvenient Past: Post-Communist Holocaust Memorialization,” Shofar: An Interdisciplinary Journal of Jewish Studies 29, no. 1 (2010): 73-94.

${ }^{27}$ Jan T. Gross, Neighbors: The Destruction of the Jewish Community in Jedwabne, Poland (Penguin Books, 2002).

${ }^{28}$ The History Commissions in Latvia and Lithuania are still on-going, whereas the Commission in Estonia ended in 2008.

${ }^{29}$ Eva-Clarita Pettai, "Establishing 'Holocaust Memory' - A Comparison of Estonia and Latvia," in Historical Memory Culture in the Enlarged Baltic Sea Region and Its Symptoms Today (Vandenhoeck \& Ruprecht, n.d.), 159-174; Jörg Hackmann, "From National Victims to Transnational Bystanders? The Changing Commemoration of World War II in Central and Eastern Europe," Constellations 16, no. 1 (2009): 167-181.
} 
Estonian narrative of victimhood. ${ }^{30}$ Jorg Hackmann looks at the representations of collective memory that historiographical and scholarly debates can provide in Poland and the Baltic states. Hackmann argues that a 'transnational perspective' has emerged within scholarship on the Second World War with the Holocaust as a key component. Key works such as Jan-Tomasz Gross' Neighbours, as well as the History Commissions of the Baltic states, have led to an increased dialogue between nations, a more explicit and open examination of their role in the Holocaust and a lessening in the nationalisation of memory. This validates Diner's thesis of the Holocaust as a European foundational myth which is becoming progressively shared by many post-Communist nations. $^{31}$

The most common theme in historiographical interpretations is the attempt to understand how public policy, historical interpretations and other lieux de memoire contribute to overall public memory of the Holocaust. Michael Shafir creates several conceptual frames in which to analyse how post-Communist East-Central Europe societies remember the Holocaust. Shafir identifies 'outright Holocaust negation', 'deflective negationism' and 'comparative trivialisation' as being the three trends in the ways in which post-Communist societies remember the Holocaust. Outright Holocaust negation is pure Holocaust denial, a rejection of the Holocaust as a factual historical event. This is relatively infrequent in Eastern Europe and indeed in Estonia, so therefore does not need to be explored. Deflective negationism "transfers the guilt for the perpetration of crimes to members of other nations, or it minimises own-nation

\footnotetext{
${ }^{30}$ Anton Weiss-Wendt, "Why the Holocaust Does Not Matter to Estonians," Journal of Baltic Studies 39, no. 4 (2008): 475-497.

${ }^{31}$ Hackmann, "From National Victims to Transnational Bystanders?".
} 
participation in their perpetration to insignificant 'aberrations "," 32 The most common forms of deflective negationism seek to place all or most of the blame onto the Nazis, thus downplaying the role of collaborators, many of whom were local fascists and collaborationist local authorities. Other more minor but nevertheless prevalent forms of deflective negationism include shifting blame to a 'radical fringe' of locals and also passing blame to Jews themselves. Comparative trivialisation of the Holocaust is:

"the wilful distortion of the record and of the significance of the Holocaust, either through the 'humanisation' of its local record in comparison with atrocities committed by the Nazis, or through comparing the record of the Holocaust itself with experiences of massive suffering endured by local populations or by mankind at large at one point or another in recorded history". 33

Comparative trivialisation is often displayed by comparing local conditions of the Holocaust with others in Europe, such as the superior conditions of concentration camps in one country as opposed to those controlled by Nazis. A more prevalent form of comparative trivialisation is the 'double genocide' argument which seeks to present the atrocities committed by the Soviet Union as equal to or worse than crimes committed by the Nazis and their collaborators. ${ }^{34}$ Diner concurs with Shafir, and presents the dilemma that post-Communist states faced in advance of the $2004 \mathrm{EU}$ accessions: how their national victimhood status would fit into the European structure, the possibility of competition or rivalry with Jewish victimhood and whether they could agree with the Western construction of the Holocaust as the foundational event that unites an expanding Europe.

Jeffrey Blutinger demonstrates three stages that have been employed in EastCentral Europe when memorialising the Holocaust: at first, aphasia (an unwillingness to

\footnotetext{
${ }^{32}$ Shafir, Between Denial and “Comparative Trivialization," 12.

${ }^{33}$ Ibid., 34.

${ }^{34}$ Shafir, Between Denial and "Comparative Trivialization."
} 
discuss the Holocaust), then deflective negationism, and finally a full and frank examination of the Holocaust including the nature of local collaboration. Blutinger stops short of linking this evolution with the nation's wider aims and policies of Western integration; however, the chronology of events can be linked to both EU and NATO accession. ${ }^{35}$

Eastern European nations have not been alone when it comes to confronting national participation in the Holocaust in the face of international scrutiny. Avi Becker looks at two cases of a 'memory war' with an international dimension relating to the Holocaust and its modern interpretation within a nation. The Austrian narrative of being Germany's 'first victim' came to international attention during the 'Waldheim Affair' in 1986 after it was discovered that Presidential candidate Kurt Waldheim had served as a Nazi Wehrmacht officer and been complicit in atrocities committed against Jews as well as Italians, Serbs and others. The Waldheim affair did not remain confined to one man, but called into question Austria's entire national collaboration in the Holocaust as well as how Austrians remembered their role. Switzerland, long proud of its neutral status during the Second World War, was also forced to confront its past between 1996 and 1997 when Swiss banks and the government were pressured by US politicians and the World Jewish Congress into formally assessing the actions and dealings of banks during the Second World War regarding their relationship with Nazi Germany. ${ }^{36}$ The effect of both cases shattered traditional memory narratives, which had been based on either victimisation or innocence, and led to a full and frank moral investigation amongst both the Austrian and Swiss public. The traditionally black and white boundaries between

\footnotetext{
${ }^{35}$ Blutinger, "An Inconvenient Past."

${ }^{36}$ Avi Beker, "Building Up a Memory: Austria, Switzerland and Europe Face the Holocaust," in Power and the Past: Collective Memory and International Relations, ed. Eric Langenbacher and Yossi Shain (Georgetown University Press, 2010), 97-121.
} 
collective guilt and collective responsibility were significantly blurred and further complicated by the growing ambiguity in what was considered 'collaboration'. It also demonstrated the changing nature of collective memory and the vulnerability of national narratives in a global, technological world and their susceptibility to influence from international forces, both state and non-state.

As stated earlier, the historical particularities of the Holocaust in Estonia remain different from many others in the vicinity who also suffered the trauma of Nazi and Soviet occupations. However, the methods used by scholars to understand other nations and regions can certainly be applied to the Estonian case as they analyse the same fundamental phenomenon: Holocaust memory in post-Communist nations seeking Western integration which have suffered the trauma of both Nazi and Soviet occupations.

\subsection{The Estonian Memory NARRATIVE AND ViCTIMHOOD}

Scholarship on memory in Estonia has flourished since 1991, and can be found in many different fields across the social sciences and history. This section will highlight key works that have been written about how Estonia remembers its past. One major theme identified by scholars is the role of the Soviet past in post-1991 memory. The national trauma suffered in 1940-1941 and again in 1944-1991, which stems from the illegality, barbarity and repressions toward Estonians, is ever-present in scholarly debates surrounding contemporary Estonian identity, with memory of the Soviet past a key ingredient. This is crucial to this thesis, which analyses Estonia's memory of the Holocaust, as the emphasis on Soviet crimes as opposed to the Holocaust is the 
fundamental 'problem' being discussed. Scholarship on Holocaust memory in Estonia is significantly thin in comparison with many other post-Communist European countries. This in itself is interesting; as it suggests that understanding how Estonia's role in the Holocaust manifests itself in national collective memory comes secondary to the study Soviet occupation's impact.

The Estonian 'War of Monuments' and 'War of Memories' are two of the terms used to describe the incidents surrounding the removal of the Lihula monument in 2004 and, more so, the relocation of the Bronze Soldier monument in Tallinn in 2007. Both incidents alerted several scholars to the pervasiveness of an emphasis on Soviet crimes in Estonian memory, as well as the current socio-cultural divides in Estonia's memory of the Second World War. Articles by Bruggemann and Kasekamp (2008) ${ }^{37}$ and Pääbo $(2008)^{38}$ reach similar conclusions regarding what the incidents suggest about memory in Estonia. Bruggemann and Kasekamp argue that the public reactions to the two incidents reflect different memories of the Second World War by the ethnic-Estonian population and the minority ethnic-Russian population. The ethnic-Estonian population overwhelmingly sees the Second World War as the beginning of a 50-year Soviet occupation. The Estonian narrative states that the Molotov-Ribbentrop pact of 1939 led to the Soviet Union forcing Estonia to submit to occupation. Estonia was subsequently invaded by another totalitarian power, Nazi Germany, before declaring independence once again. The Soviets crushed Estonian independence for a second time and submitted Estonia to 45 years of subsequent occupation, and, given the flight of many Russians to Estonia during the Soviet era, many go so far as to claim that it was

\footnotetext{
${ }^{37}$ Karsten Bruggemann and Andres Kasekamp, "The Politics of History and the 'War of Monuments' in Estonia," Nationalities Papers 36, no. 3 (July 2008): 425-448.

${ }^{38}$ Heiko Paabo, "War of Memories: Explaining 'Memorials War' in Estonia," Baltic Security and Defence Review 10 (2008): 5-28.
} 
colonisation. ${ }^{39}$ Many members of the Russian minority of Estonia, which today forms approximately $25 \%$ of the population, view the events of the Second World War and subsequent post-war era markedly differently. They see Estonia as voluntarily agreeing to be a part of the Soviet Union in 1940 and that the country was being liberated by the Red Army in 1944. The Russian narrative, which is promoted by the government of the Russian Federation, is effectively identical to the Soviet 'Great Patriotic War' narrative. Thus, Estonian memory of the Second World War is dominated by a feeling of victimisation and most importantly defined as a time of Estonian suffering brought about by Russian aggression. ${ }^{40}$

Another recent expression of 'the politics of memory' in regard to the Soviet era in Estonia and interpretation of the Second World War can be found in Eva-Clarita Onken's article which discusses the Baltic states' reactions to Russia's invitation to the $9^{\text {th }}$ May World War II Commemoration in Moscow in 2005. The commemorative day, seen by Russia as a time of victory, is not viewed by the Baltic states in the same way and is a day of mourning due to its association with the beginning of decades of Soviet occupation. Onken argues that there are three levels of analysis required in order to find the link between political decision-making and memory in Europe: domestic memory politics, memory politics in bilateral relations and memory politics in the European Union. The decision by Estonian President Arnold Rüütel to reject the invitation to Moscow was influenced by these three key factors. Domestic memory politics, recently highlighted by the 2004 Lihula statue incident that had led to fierce public historical debate, clearly influenced Rüütel's decision. The ethno-political dimension of both domestic memory as well as its role in bilateral relations with Russia and Estonia was

\footnotetext{
${ }^{39}$ Bruggemann and Kasekamp, "The Politics of History and the 'War of Monuments' in Estonia," 429. ${ }^{40}$ Ibid.
} 
also a key factor. Rüütel's decision within the context of European memory demonstrates a willingness to place Baltic memory on the European agenda, where there is an East-West divide over the interpretations of Nazi and Soviet crimes. ${ }^{41}$ Onken's study importantly demonstrates that memory is influenced not solely by national political factors but also by international elements.

Kirsti Jõesalu analyses how memory of the Soviet past is represented amongst the political elite in Estonia through an analysis of speeches given by three Estonian Presidents. She argues that Presidential speeches convey both the personal, everyday experiences of Presidents during the Soviet-era while reflecting the wider national collective memory of Estonia. The effect of this is to create a 'usable past' for a wide audience, which allows elite politicians to connect with citizens whilst also achieving broader national political goals. Jõesalu's analysis finds that the most salient themes within the discourse of Estonia's Soviet past are those of 'rupture' and 'resistance'. 'Rupture' stresses that Estonia's national development was brought to an abrupt end in 1940, and 'resistance' shows that Estonia continued to be guided by national consciousness throughout the Soviet period. These themes and the extent to which each President conveys them are reliant on the personal experiences of the respective President. For example, Lennart Meri, who suffered directly from Soviet deportations, emphasises the negative impacts of the Soviet Union in day-to-day life, whereas Toomas Hendrik-Ilves, who never lived in the Soviet Union, focuses on how Estonia was betrayed by world politics. ${ }^{42}$

\footnotetext{
${ }^{41}$ Onken, "The Baltic States and Moscow's 9 May Commemoration."

${ }^{42}$ Kirsti Joesalu, "The Role of the Soviet Past in the Memory Politics Through Examples of Speeches from Estonian Presidents," Europe-Asia Studies 64, no. 6 (August 1, 2012).
} 
Pille Petersoo utilises memory as a tool to identify how Estonian identity is constructed, and shows the defining role played by the Soviet Union and Russia in shaping it. Reconsidering Otherness analyses the role played by the 'other' in Estonian identity, that is, how Estonians as a nation define themselves by comparing themselves to an oppositional force. Petersoo states that there are four types of 'other' in the Estonian case, all of which are components of Estonia's identity construction: the internal positive, internal negative, external positive and external negative. The internal positive other is a group that is defined as non-Estonian but present within Estonia, and having a positive influence in Estonian identity construction. This group is identified as the Baltic Germans, once seen as the ruling class and enemy of the Estonians, but now as having a historically positive influence in many areas of Estonian culture and society. The internal negative other is one that is non-Estonian and present in Estonia but that has a negative influence as the other in Estonian identity construction. Petersoo describes this group mainly as the ethnic-Russian minority, especially those of its members who arrived during the Soviet occupation. There is a perception of the Russians living in Estonia as the antithesis of Estonians and the bearers of Russian imperialism and colonisation. The external positive group is one that exists outside of Estonia and has a positive impact on Estonian identity construction. Major positive influences on Estonia from outside are Finland, Scandinavia and continental Europe in general, which all shares many historical, cultural, linguistic and economic ties with Estonia. The external negative other is one that exists outside of Estonia and is viewed negatively in the context of Estonian identity. This group is identified as Russia, which is seen as an imperialist threat. ${ }^{43}$ The common theme in Petersoo's work is that Russians

\footnotetext{
${ }^{43}$ Pille Petersoo, "Reconsidering Otherness: Constructing Estonian Identity*," Nations and Nationalism 13, no. 1 (2007).
} 
and Russia are viewed negatively in terms of Estonian identity and are seen as a threatening 'other' and everything the Estonian is not.

In a study of Estonian cultural memory, Marek Tamm analyses the historical narrative presented in Estonian cultural practices such as commemorations and public rituals. He identifies the 'Great Battle for Freedom' narrative as the most salient aspect of how Estonian history has been represented, particularly during the first period of independence (1919-1939). The Great Battle for Freedom narrative states that Estonians as a people and nation have been the victims of oppression ever since the $13^{\text {th }}$ century by outside forces, mainly Germans. The culmination and climax of the Great Battle for Freedom was during the Estonian War of Independence in 1918, when the Landeswehr was driven out of Estonia and the Soviet Union was defeated. Tamm's work focuses on the interwar period; however, he also stresses the continuity of the Great Battle for Freedom narrative into post-1991 Estonian history. ${ }^{44}$ Interestingly, Tamm highlights the Baltic Germans as the main 'other' in Estonian memory, which is unsurprising as his study focuses on the interwar period. It demonstrates that the victim status which has been present in Estonian memory following re-independence in 1991 predates the Soviet and Nazi occupations. Therefore, Estonian historical writing ever since its inception in the late $19^{\text {th }}$ century, has tended to view Estonians since the $13^{\text {th }}$ century as victims, a practise which was institutionalised by the state following independence in the interwar period and has continued since re-independence.

In order to demonstrate the Estonian memory narrative in a more tangible sense, several scholars have analysed the Baltic Museums of Occupation within different

\footnotetext{
${ }^{44}$ Marek Tamm, "History as Cultural Memory: Mnemohistory and the Construction of the Estonian Nation," Journal of Baltic Studies 39 (2008): 499-516.
} 
scholarly frameworks. Burch and Zander analyse the Estonian Museum of Occupations from the perspective of art history and museology. They ultimately set out to analyse how the past is presented in the museum and the ways in which Estonia's Soviet past has been displayed. They argue that the museum attempts to bury the past and also serves a political and moral function as a warning from history. They place special emphasis on the Soviet statues that have been re-situated from their prominent places in the urban landscape into the dark corners of a small building. Within the context of the recent Bronze Soldier crisis, Burch and Zander argue that the museum's attempt to bury the past has ultimately failed, as history still clearly plays a prominent role in Estonian society, particularly in terms of its ethno-political divisions. ${ }^{45}$ Aro Velmet looks at the Baltic Museums of Occupation within the context of their post-Soviet historical narratives from a more political-memory perspective. Velmet argues that all three Occupation Museums in Lithuania, Latvia and Estonia accurately reflect the state-level representations of Soviet crimes and national victimhood and are 'trapped in the dominant ideologies' of elite representations of memory. ${ }^{46}$

One can gather from the scholarly works on Estonian memory that a feeling of victimisation dominates its discussion. Memory of the Soviet past plays heavily on the post-1991 present and has contributed significantly to post-Soviet Estonian identity. This victimisation would seem to be a continuation of what Marek Tamm refers to as the Great Battle for Freedom narrative, only with a different 'victimiser'. There has been a notable transition from a demonization of Baltic Germans as the 'other' to the Russians, clearly brought about by the Soviet occupation. The findings within the

\footnotetext{
${ }^{45}$ Burch S. and Zander Ulf, "Preoccupied by the Past The Case of Estonian's Museum of Occupations," Scandia 74, no. 2 (2008): 53-73.

${ }^{46}$ Aro Velmet, "Occupied Identities: National Narratives in Baltic Museums of Occupations," Journal of Baltic Studies 42, no. 2 (2011).
} 
review of literature not only demonstrate some of the common approaches to understanding memory, but also highlight in the case of Estonia a logical explanation for why memory of the Holocaust does not influence national Estonian collective memory to the same extent it has in other nations.

The obvious question at this point which relates to this study is; how can one relate the Estonian-Russian memory dynamic with the Estonian-Jewish dynamic? There are similarities in terms of how the Estonian memory narrative of victimhood gives preferential treatment to ethnic-Estonians, leaving other ethnic minorities including Russians and Jews on the periphery (this trend will be explained in more detail later on during the museum analysis). However, that is where the similarities end. Russians hold a complex role in Estonian identity construction due to their prominence in Estonian history as well as the current sizeable ethnic minority in Estonia which arrived during the Soviet era. The Jewish community in Estonia has always been numerically tiny in comparison. The role ascribed to Russians in Estonian identity is complicated further by geopolitics and diplomatic relations, which have been relatively frayed since Estonian re-independence. What identifies the Jews and the Holocaust in Estonia memory as unique is its transnational nature, and the fact that it has only become a main subject of scholarly debate since Western integration. It is this phenomenon of the Holocaust being brought onto the Estonian domestic political agenda by international actors which this study is interested in and will look to elucidate throughout.

This thesis thus aims to address an important gap in the scholarly literature of Estonian memory. The Holocaust has been neglected as an important area of study by scholars who tend to, not without good reason, focus almost entirely on the crimes committed against Estonians by the Soviet Union and how this has manifested itself in 
contemporary political discourse. There is a small literature specifically aimed at looking at Holocaust memory in Estonia, and some interesting work has been done mainly on Holocaust education (or lack thereof), history commissions as well as contemporary anti-Semitism. ${ }^{47}$ This study will look to create a broader overview of Holocaust memory as constructed at the elite political level, both in its domestic and international context. By analysing speeches and museums that have not before been analysed specifically for what they suggest about the politics of Holocaust memorialisation as well as the activities, publications and policies of international organisations, a fresh angle will be provided, which will hopefully add to the growing picture of Holocaust memory started by Doyle Stevick, Eva-Clarita Pettai and Anton Weiss-Wendt. The findings of this thesis are relevant to memory studies in Europe broadly and should not be only contained within the field of 'Estonian studies'. The impact of the Holocaust memory on European integration and its role in European relations since the 2004 accessions of post-Communist East European nations is explored in great depth, as it is within this context that the case of Estonia is so relevant.

\footnotetext{
${ }^{47}$ These works by Doyle Stevick, Eva-Clarita Pettai and Anton Weiss-Wendt will not feature in the literature review, as they are discussed frequently throughout the study.
} 


\section{Chapter Three: Theory \& Methodology}

Memory studies as a broad, multidisciplinary field is exceptionally diverse in nature. It is therefore difficult to pin down and 'apply' a specific theoretical structure to work under, even in better defined areas such as political memory. Scholars have found much greater efficiency in drawing on some of the main claims and methods of others in the field of memory studies, and looking to understand a causal relationship between a particular case study and the methods used by other scholars. This theoretical section will therefore highlight the methods, concepts and theories used by other scholars in the field of political memory studies and look to use them in order to form a causal relationship with the case study findings discussed in the analysis section. Most of the works that are included will be utilised for their theoretical and conceptual value are in the literature review and are closely related to the broad phenomena being discussed: political memory of the Holocaust.

In order for this study to be conceived at a more abstract level, aspects of the study need to be divided and theoretically conceptualised. First, political memory and how it will be applied in this thesis will be examined. Second, the international dimension of Estonian Holocaust memory politics will be discussed. This section will be directed by Eva-Clarita Onken's 'three level analysis' (with some minor amendments) and Levy and Sznaider's concept of 'cosmopolitan memory'. Thirdly, manifestations of political memory will be analysed using the studies of Jeffrey Blutinger, Aro Velmet, Michael Shafir and Kirsti Jõesalu in order to direct the study of museums, speeches and commemorative practices as particular forms of collective memory constructions and how these present a discourse of the Holocaust. Finally, the 
methodology will be explained in terms of how it was applied and how sources were chosen.

\subsection{DEFINING POLITICAL MEMORY}

In order to understand how memory will be analysed in this thesis, it is essential that a working-definition of 'political memory' is presented. This is clearly a difficult task, given the vast amount of literature written with varying interpretations of memory. Thus, in order to build a theoretical framework, this section will look to utilise the definitions and works of scholars who recognise the link between domestic memory and international memory, and the relationship between the two. These will come from the work of Eric Langenbacher, Jan Werner-Müller and Richard Ned Lebow.

Ever since Maurice Halbwachs formally proposed the concept of 'collective memory, ${ }^{48}$ this extremely broad term has been the subject of much discussion, scholarly debate and attempts to operationalize into more succinct categories. The most important definitional distinction to make at this point is the difference between cumulative individual memories and public memory. Jeffrey Olick picked up on the differences between the two; public memory is a construct and the subject of change and operationalization, whereas individual private memories are those held by individuals of a given entity (social group or nation), but do not necessarily cumulate as memory which is held by wider society. ${ }^{49}$ Timothy Snyder also recognises this important distinction, that 'mass personal memory' is different to public memory which

\footnotetext{
${ }^{48}$ Maurice Halbwachs, On Collective Memory, trans. Lewis A. Coser, 1st ed. (University Of Chicago Press, 1992).

${ }^{49}$ Jeffrey K. Olick, "Collective Memory: The Two Cultures," Sociological Theory 17, no. 3 (November 1, 1999): 333-348.
} 
is the construct of elites. ${ }^{50}$ Aleida Assmann makes an even greater distinction between forms of collective memory, separating them into; communicative, generational, collective and shared memories within a cultural context. ${ }^{51}$ This thesis is entirely interested in public memory; memory which is constructed by the political elite. It thus doesn't necessarily take into account 'mass personal memory'. The importance of understanding individual and social memories of Estonians and the Holocaust cannot be understated. However, in order to conduct such a study, much greater time and resources would be needed than this thesis allows for. The emphasis this paper has on public memory is also important in terms of its implications; the conclusions drawn on state-level constructions of the Holocaust narrative should not be misinterpreted as something which each and every, or even a majority of Estonians subscribe to. Clearly, in a pluralist democracy memories from different ethnic and social groups are designed to be allowed to flourish, and thus whether individual citizens choose to accept the narrative is entirely reliant on personal choice. Rather, the analysis of memory construction should be viewed within the context of elite political culture and the need to create a narrative of the Holocaust which serves both domestic and international political interests.

Langenbacher views memory as an important factor in political culture. He defines collective memories as "intersubjectively shared interpretations of a poignant common past with a high degree of effect". ${ }^{52}$ Collective memories are mutually

\footnotetext{
${ }^{50}$ Timothy Snyder, "Memory of Sovereignty and Sovereignty over Memory: Poland, Lithuania and Ukraine, 1939-1999," in Memory and Power in Post-War Europe: Studies in the Presence of the Past, ed. Jan-Werner Müller (Cambridge University Press, 2002), 57-58.

${ }^{51}$ Jan Assmann and John Czaplicka, "Collective Memory and Cultural Identity," New German Critique no. 65 (April 1, 1995): 125-133; Aleida Assmann, "Transformations Between History and Memory," Social Research 75, no. 1 (Spring 2008): 49-72,354.

${ }_{52}$ Eric Langenbacher and Yossi Shain, eds., Power and the Past: Collective Memory and International Relations (Georgetown University Press, 2010), 26.
} 
constitutive of identities and thus a collective memory provides an identity which is communal, and shared. Langenbacher also demonstrates how collective memories are the constructs of elite members of society, whether it is politicians, intellectuals, journalists among others, and views this within a Gramscian framework of cultural hegemony. This in many ways implies that a hegemonic and authoritarian political structure means a more direct control over memory and its greater use as a political tool. This is not the case according to Langenbacher, who argues that memory within a pluralist democracy with competing interest groups provide the best environment for memories to flourish. ${ }^{53}$ Lebow follows on from this view of memory being an eliteconstruct, but not necessarily an all-encompassing and controlling narrative. 'Institutional memory' exerts 'imperfect control' over society, and thus cannot be seen as a representation of the nation-at-large's attitudes. Lebow also states that changes in the discourse of memory narratives, in democracies, tend to be a gradual process as opposed to abrupt changes of direction. ${ }^{54}$ Jan-Werner Müller views memory as having 'symbolic power' which is executed in the same fashion as material power and by the same people; elites. It is embedded within the political culture of a given nation and thus memories can be seen as 'cultural capital'. The uses of memory amount to "strategic public claim-making" and demonstrate a struggle over what meaning to assign to certain historical events within a given cultural context. It must be noted that Müller's analyses is more related to specific policy initiatives which are influenced by memory and not so much the commemorational aspect which this thesis deals with. However his definition nevertheless influences how and why commemorations are

\footnotetext{
${ }^{53}$ Ibid., 26-38.

${ }^{54}$ Richard Ned Lebow, Wulf Kansteiner, and Claudio Fogu, eds., The Politics of Memory in Postwar Europe (Duke University Press Books, 2006), 14-16.
} 
executed by the political elite, which in the case of Estonian Holocaust memory, reflect broader policy trends in regards to Western integration. ${ }^{55}$

So if we define memory as an elite-driven product of political culture within a nation how do external influences influence this? Much of this debate falls into the debate of international relations theory, between realists and constructivists who believe that foreign policy decisions are driven by political culture. Langenbacher argues that there is a growing consensus of scholars who recognise the political culture, which is subject to external pressures and influences, is influential in constructing memory at the national level. ${ }^{56}$ Müller argues, in keeping with constructivist thinking, that the foreign policy decisions of states whilst clearly affected by material interests, are executed within the framework of a political culture, of which memory is an important component. ${ }^{57}$ Lebow defines into three categories, the relationship between international external influences and memory; international, transnational and crossnational. International relates to the behaviour of other states, transnational relates to non-governmental organisations and professional groups such as academia, crossnational relates to more ambiguous methods such as discussions and experiences of citizens abroad and discussions by foreign media groups. ${ }^{58}$ In this thesis, the latter will be excluded and the first two operationalized in order to understand the dynamics of memory in international relations.

To summarise, memory will be defined as public memory in this thesis. Public memory is an elite-based construction of historical events which serve a political

\footnotetext{
55 Jan-Werner Müller eds., Introduction. Memory and Power in Post-War Europe: Studies in the Presence of the Past (Cambridge University Press, 2002), 25-31.

${ }^{56}$ Langenbacher and Shain, Power and the Past, 18-19.

${ }^{57}$ Müller, Memory and Power in Post-War Europe, 28-31.

${ }^{58}$ Lebow, Kansteiner, and Fogu, The Politics of Memory in Postwar Europe, 25-26.
} 
purpose and is utilised by political elites as a form of socialisation. This must not be confused with private and individual memories, which are often likely to differ from the official state narrative and subject to much less influence from external influences. Public memory is influenced by external international forces and 'outsiders', both state and non-state. In the case of this thesis, intervention from international forces (statelevel) and transnational groups (NGOs and professional groups) will be assessed for their influence on Estonian public memory of the Holocaust. Now a working definition of memory has been identified, the following two sections will go into greater detail mapping out the framework of this thesis which addresses both domestic and international memory.

\subsection{INTERNATIONAL AND TRANSNATIONAL MEMORY}

The second part of the theory section will delineate how Estonian memory of the Holocaust can be understood within an international context. This broadly agrees with much contemporary literature on collective memory studies in the political context which suggest that there is a growing transnational approach to memory and a decreasing reliance on national memory narratives which shape the public perception of history.

One of the key tasks of this thesis is to demonstrate how international forces brought the Holocaust onto the Estonian Government's agenda. Onken's three-level framework will be especially useful in theoretically structuring the relationship between international forces, political decision-making and memory. Onken highlights two international forces - memory politics within bilateral relations and supranational 
memory politics within the European Union, as being important factors on domestic political elites in Europe. Bilateral relations can be influenced by both mass individual memory and national collective memory, often in the form of disputes relating to ethnic minorities, for example, the impact that the Russian minority in Estonia has on RussianEstonian relations. Memory politics within the European Union relates to the numerous conflicts between member states and supranational institutions within an enlarged Europe. This is often conceptualised as an East-West conflict, as many former Communist states look to bring their own historical sufferings caused by Communism onto the European agenda. This conflict over memory seen at a supranational level is particularly relevant as a contextual framework in understanding Estonia's interaction with European institutions which deal with Holocaust memory. ${ }^{59}$

Whilst Onken demonstrates a clear analytical structure which looks at the relationship between international forces and memory, Eric Langenbacher also recognises the need for a more transnational approach to memory and highlights the increasing consensus that memory is an important factor in international relations within the constructivist school. He argues that memory which influences domestic political culture or 'memory regime' ultimately influences the foreign policy decisions of a state. Memory also impacts upon international institutions, both supranational and intergovernmental, and these institutions can often be at the centre of disputes over memory, whether it is with another institution or a national government, or can even be the creator of a dispute between a national government and its domestic population. Interestingly, there is a growing number of non-governmental and non-state actors involved which look to influence policies, attitudes and debates among people.

${ }^{59}$ Onken, "The Baltic States and Moscow's 9 May Commemoration," 26-31. 
Langenbacher specifies the effectiveness of Jewish lobby groups in influencing issues relating to upholding Jewish memory. Langenbacher ultimately argues, in line with Daniel Levy and Nathan Sznaider, that there is a growing trend in political memory with a "transnational infrastructure" 60 or 'cosmopolitan memory'.

Daniel Levy and Nathan Sznaider discuss the changing nature of collective memory in the modern age as an increasingly transnational phenomenon, and look to "Rather than discarding the concept of collective memory, we are transposing it from the confines of its formerly national context to a broader global one". ${ }^{61}$ The functions of collective memory, they argue, can only be understood when discussed in a global context, which they term as 'cosmopolitan memory'. Levy and Sznaider primarily analyse memory in the cultural sphere and its relation to the decline of the nation-state. On the other hand, cosmopolitan memory can easily be transferable to the arena of politics within the context of European integration, where the nation-state has become decreasingly sovereign over various aspects of political life. This divestment of sovereignty can be applied to memory, and the political culture in which memory has been constructed has become more 'Europeanised'. Levy and Sznaider, as the defining example of cosmopolitan memory, use the Holocaust. The Holocaust has become the global measuring stick of good and evil, they argue, and become displaced from its original context. It is used in the global age as an abstract concept and one which frequently crops up in both political and cultural spheres as justification for halting human rights abuses and atrocities. ${ }^{62}$

\footnotetext{
${ }^{60}$ Langenbacher and Shain, Power and the Past, 18-20.

${ }^{61}$ Levy and Sznaider, Holocaust And Memory In The Global Age, 25.

${ }^{62}$ Ibid., 23-38.
} 


\subsection{DOMESTIC MEMORY}

Onken's study of the politics of memory in the Baltic states will be also highly influential in terms of its 'domestic' theoretical framework. Onken documents the different ways in which issues relating to memory have been highlighted in the domestic political setting and are particularly prevalent in post-authoritarian societies following a transition to democracy. These are often cases of transitional justice, and ensuring that crimes committed against the local population are brought to the forefront is a way of coming to terms with the past. There is also a political-cultural aspect, which relates to the politics of commemoration in forms such as ceremonies, national holidays and public speech commemorations. Memorials and education are also part of this political-cultural dimension and demonstrate the construction of historical images and deliberately created sites of memory (lieux de mémoire). ${ }^{63}$ Onken analyses memory politics in the domestic setting as being elite-based and neglects the public consumption dimension which Langenbacher explores through a more quantitative analysis of public opinion. However, Langenbacher does agree that 'memory regimes' are almost always elite-based and "elites produce the texts through which the political-cultural phenomena such as collective memories manifest themselves", ${ }^{64}$

The first part of the analysis of domestic Estonian Holocaust memory will be through an examination of speeches. Kirsti Jõesalu uses speeches as a form of commemorative practice in order to study the role of the Soviet past in Estonian elite political discourse. She asks specific questions of the speeches in order to direct her inquiry: "What meaning is attributed to the Soviet period? What is the connection

\footnotetext{
${ }^{63}$ Onken, "The Baltic States and Moscow’s 9 May Commemoration."

${ }^{64}$ Langenbacher, "Twenty-first Century Memory Regimes in Germany and Poland An Analysis of Elite Discourses and Public Opinion," 53.
} 
between the presidents' life experiences and the messages they convey? How do their texts relate to other memories of Estonian society?" 65 The speeches she analyses are all conducted on commemorative days within the Estonian national calendar, such as $23^{\text {rd }}$ June 'Victory Day', and are viewed as a "type of mnemonic practice used in the contexts of certain media of memory". ${ }^{66}$ Her analysis of speeches seeks to understand the different layers of commemoration, political rhetoric and memory narrative discourse and avoids treating memory as 'homogenous' by assuming there is only one interpretation of the past. Mihkail Bahktin had also highlighted the value of using speeches in the analysis of memory, arguing that they are a type of memory expression which defines "the object, the goal and the situation of utterance". ${ }^{67}$ Therefore, speeches are a powerful tool of analysis in understanding what memory narrative the political elite is trying to construct, how they are doing it in terms of words and meaning and where it occurs in terms of the location, commemorative day, place, memorial etc.

The second part of the analysis of domestic Holocaust memory is an analysis of museums. Museums are a useful manifestation of collective memory or lieux de memoire as they are deliberately created and institutionalised sites of memory in which one can find a constructed, financed and displayed version of history. Burch and Zander argue "that museums shape national history and collective memory - thereby justifying present as well as articulating the past-means that they are both valued and valueladen sites". ${ }^{68}$ They argue that museums are both manifestations of collective memory and themselves constructors of collective memory. Velmet argues that:

\footnotetext{
${ }^{65}$ Joesalu, "The Role of the Soviet Past in the Memory Politics Through Examples of Speeches from Estonian Presidents," 1013.

66 Ibid.

${ }^{67}$ Ibid., 1014.

${ }^{68}$ S. and Ulf, "Preoccupied by the Past The Case of Estonian's Museum of Occupations," 55.
} 
"The Baltic museums of occupations provide three attempts at writing the final chapter for the national narrative of their respective countries. Though purportedly academic institutions of critical inquiry, museums are also discursive establishments, conduits of power transmitting and shaping narratives of national identity through their scholarly and political authority". ${ }^{69}$

Velmet's typology fully appreciates the power and usefulness of museums as an area of study when analysing collective memory. Every museum contains a top-down, constructed narrative or story and can also demonstrate the power dynamics of national identity and its construction by elites.

This thesis will first analyse Holocaust memory within the framework of international memory politics by looking at 'supranational Holocaust memory' and a discussion of how international influence pushed the Holocaust onto the political agenda in Estonia. Following the international dimension, the domestic manifestations of Holocaust memory will be analysed. As discussed earlier, domestic collective memory is conceptualised as top-down and elitist. Therefore by analysing the speeches of elite Estonian politicians at commemorative ceremonies such as the $8^{\text {th }}$ May and Holocaust Memorial Day, one is able to analyse what memory narrative of the Holocaust is being constructed and how it relates to the broader context of Estonian collective memory. The analysis of the Estonian History Museum, Museum of Occupations and Estonian Jewish Museum will further support this method of study, as museums are also top-down commemorations which look to present and construct a particular version of history. These approaches will allow a conclusion to be drawn from the main research questions of this study: how has the political elite balanced the

$\overline{{ }^{69} \text { Velmet, "Occupied Identities," } 190 .}$ 
demands of the international community with those of the domestic population with regard to Holocaust memory?

\subsection{MeThodology}

This study will use a secondary source analysis both as a means of developing a theoretical framework in concert with other scholars who have written on similar topics and also to place the study within the context of other existing scholarly literature on Holocaust memory in both Estonia and other post-Communist EU member states. Primary sources will be the main subject of analysis, and will comprise documents of non-governmental, state and intergovernmental agencies, speeches of elite Estonian politicians and museum analysis.

In order to understand the domestic politics of Holocaust memory, speeches will form a large part of the primary source evidence. In total, nine speeches have been analysed from the period 2005-2012: two speeches by former Estonian President Arnold Rüütel, three speeches by Prime Minister Andrus Ansip, two speeches by President Toomas Hendrik Ilves and two speeches by Foreign Minister Urmas Paet. They were obtained directly from the Government database found on their respective departmental webpages. The speeches chosen all make direct reference to either the Holocaust or Estonian-Jewish relations and can thus be seen as attempts by the national political elite to deliver a top-down communication which contains the stance of the individual politician in his role as an elite representative of the state of Estonia. They will be assessed in the same manner as other scholars such as Jõesalu have done, by asking specific questions: What references are made to the Holocaust? Within what context is 
the Holocaust being discussed? Is the event or commemoration where the speech was delivered important? How does the discussion of the Holocaust in the speech agree or disagree with the Estonian memory narrative of victimisation?

Another primary, empirical source used was an analysis of museums. The museums analysed were the Estonian History Museum, Museum of Occupations and the Estonian Jewish Museum, all in Tallinn. The specific aspects of the museums that were analysed were the content of displays and exhibitions, pamphlets, historical guides, visual artefacts, the architecture and design as well as funding and operations of the museum. Museums, as mentioned earlier, can be analysed as top-down constructions of memory. The museums have been read like a text for their literal as well as their symbolic content, which can both be seen as attempts to represent a particular narrative or version of history. Museums have been a valuable source for many scholars of collective memory, including two excellent works on both Holocaust memory in East-Central Europe by Jeffrey Blutinger and national memory narratives in the Baltic states by Aro Velmet. Both studies use museums as texts and as representations of memory narratives that are indicative of wider trends. Therefore, the museums will be seen as specific sites of memory which demonstrate their own interpretation of history, as well as being indicative of wider trends in Estonian collective memory. 


\section{Chapter FOUR: Estonian Holocaust MEMory in ITS International}

\section{CONTEXT}

\subsection{Supranational Holocaust Memory}

Following the restoration of independence in 1991, Estonia was able to reestablish an independent state and return to the liberal-democratic system it had adopted in 1920 and maintained until the Pats coup of 1934. The nation subsequently embarked upon a rapid course of development and westernisation, culminating in its joining of the European Union and NATO in 2004 and the Eurozone in 2011. It would not only become subject to the laws and regulations concocted in Brussels, but also to a European culture which has had over half a century to come to terms with the Second World War.

The first signs of a pan-European collective memory emerged following the immediate post-war period and were centred on the sole guilt of Germany for the crimes of the war. The myth of sole German guilt developed into the myth of national resistance as well as a continuation of victim status for Nazi-occupied territories until the 1970 s in what Judt refers to as the 'collective amnesia' of Europe. ${ }^{70}$ Increasing European integration would lead to the birth of a new collective memory myth, and the Holocaust would now become what Dan Diner terms the 'foundational myth of Europe', a seminal event which guards the legitimacy of the European community and the yardstick of modern morality. ${ }^{71}$ Scholars have looked to pinpoint exactly the

\footnotetext{
${ }^{70}$ Tony Judt, "The Past Is Another Country: Myth and Memory in Postwar Europe," Daedalus 121, no. 4 (October 1, 1992): 83-118.

${ }^{71}$ Dan Diner, "Restitution and Memory: The Holocaust in European Political Cultures," New German Critique no. 90 (2003): 36
} 
moment or issue which led the Holocaust to become prominent in European-wide collective memory including Marvin Chomsky's TV series, Holocaust: The Story of Family Weiss in 1978 and 1979 which drew an audience of 220 million viewers. The trial of Adolf Eichmann, as well as the growing role of Israel in world politics brought about by the Six Day War in 1967, have also been seen as turning points; however, Banke points to the Historikerstreit which reflected the complexities of Germany's coming to terms with the past; something that required active participation from government, scholars and the public. Western European countries struggled equally to address their role in the Holocaust for decades. France's inability to discuss the Vichy Occupation openly, Judt argues, had a huge impact on the whole of Europe and lasted until the mid-1990s. ${ }^{72}$

Banke argues that there were three phases in Europe's coming to terms with the Holocaust following the Nuremburg trials. The first, in the immediate post-war period was the widespread dissemination of photographs taken by soldiers and camp survivors which clearly indicated the unique barbarity that took place during the Holocaust. They were heavily linked still with Nazi guilt for the crimes and never really questioned those crimes beyond their initial shock value. The second phase which began in the 1950s was a more abstract and symbolic memory found in the artistic and cultural sphere. Many begged the question: Was Western civilisation responsible for the Holocaust and did it represent its collapse? The political left in particular used the Holocaust as a critique of capitalism and an example of the West's moral decline. ${ }^{73}$ The final, current phase,

\footnotetext{
${ }^{72}$ Cecile Felicia Stokholm Banke, "Remembering Europe's Heart of Darkness: Legacies of the Holocaust in Post-war European Societies," in A European Memory? Contested Histories and Politics of Remembrance, by Małgorzata Pakier and Bo Stråth, Contemporary European History 6 (Oxford: Berghahn Books, 2010), 163-174; Judt, "The Past Is Another Country."

${ }^{73}$ Cecile Felicia Stokholm Banke, "Remembering Europe's Heart of Darkness: Legacies of the Holocaust in Post-war European Societies."
} 
which is arguably a main component of 'supranational Holocaust memory', marked the expansion of the memorial culture. This can be found across Europe and indeed the world in many different cultural and political spheres. The doubt which plagued European nations was taken over by confrontation, a willingness to deal with the Holocaust and its legacies. It is this third phase of memorialisation that gave birth to the Stockholm Conference in 2000, the International Holocaust Remembrance Alliance and the European Agency for Fundamental Rights, as well as the plethora of state-led museums, monuments, educational initiatives and political apologies. It can also be seen as the beginning of memorialisation within the cultural and artistic spheres or the 'Schindler's List syndrome': a willingness to confront the Holocaust and its complexities head-on.

This Western-European-centric culture of memorialisation would only be questioned significantly in the build-up to and accession of ten post-Communist states to the European Union in 2004, and it is within this group that Estonia finds itself. The 'Holocaust vs. Gulag' dispute emerged most palpably during the lead up to the Prague Declaration on European Conscience and Communism in 2008. ${ }^{74}$ The Prague Declaration was an initiative of the Czech government and called for an "all European understanding that both the Nazi and Communist totalitarian regimes [...] should be considered to be the main disasters that blighted the $20^{\text {th }}$ century" ${ }^{75}$ Elements of the Prague Declaration in 2008 led to a Resolution on European Conscience and Totalitarianism in 2009. This led to a series of educational initiatives and the

\footnotetext{
${ }^{74}$ European Parliament, "European Parliament Resolution of 2 April 2009 on European Concscience and Totalitarianism," April 2, 2009, http://www.europarl.europa.eu/sides/getDoc.do?pubRef=//EP//TEXT+TA+P6-TA-2009-0213+0+DOC+XML+V0//EN\&language=EN.

75 "New German President Faces Touch of Apprehension in Israel," The Times of Israel, accessed April 17, 2013, http://www.timesofisrael.com/new-german-president-criticized-for-equating-nazism-withcommunism/.
} 
implementation of 'Black Ribbon Day', "a Europe-wide Day of Remembrance for the victims of all totalitarian and authoritarian regimes" to be held annually on August $23^{\text {rd }}$ (the day of the Molotov-Ribbentrop Pact). ${ }^{76}$ The declaration, despite its obvious controversy of equating Nazi and Soviet crimes, can be seen as a landmark moment in supranational memory politics. It was criticised heavily by various groups and individuals, from the centre-right magazine The Economist to the Simon Wiesenthal Centre, many in the Israeli media and others. There has also been an attempt by many post-Communist member states proposing legislation on denial of Soviet crimes similar to that of Holocaust denial, but have had attempts rebuffed by the European Commission. $^{77}$

The current nature of memory politics in Europe is thus on-going and dynamic. The conflict of memory seen at the European level can be seen at a micro-level in Estonia in relation to the Holocaust, and the following section will detail exactly how Western integration led to the Holocaust appearing on the national political agenda.

\footnotetext{
76 "EU Shuns Law on Communist Crimes," BBC, December 22, 2010, sec. Europe, http://www.bbc.co.uk/news/world-europe-12059475.

${ }^{77}$ Leigh Phillips, "EU Rejects Eastern States' Call to Outlaw Denial of Crimes by Communist Regimes," The Guardian, December 21, 2010, sec. World news, http://www.guardian.co.uk/world/2010/dec/21/european-commission-communist-crimes-nazism.
} 


\subsection{INTERNATIONAL AND TRANSNATIONAL INTERVENTION}

This thesis loosely defines 'Westernisation' as Estonia's integration into the European Union and NATO. The impact of these two institutions on issues of Holocaust remembrance is rather different however. NATO, as a security and defense co-operation agreement, clearly has no specific accession criteria which requires coming to terms with the past. Rather, the indirect relationship between Holocaust memory and NATO accession will be analysed which is most clearly seen in a bilateral form, especially between the United States and Estonia. The US has shown itself to be a strong international promoter of Holocaust research, memoralisation and education in both the cultural and political spheres. One may speculate on the reasons for this, and Peter Novick argues that the close relationship with Israel and the US as well as the influence of domestic Jewish organizations on foreign policy decisions ${ }^{78}$ is among the reasons why they take such a proactive role in Holocaust memory globally. US memory of the Holocaust is therefore also present within NATO and given their dominance in the organisation, they have been seen to encourage some nations, including Estonia, to reach a certain degree of consensus on remembering the Holocaust. Similar to NATO, the European Union has no tangible criteria on Holocaust memory in its accession criteria. However, Estonia as a member state is obliged or strongly recommended to become a member of various EU-led organisations and institutions, some of which are autonomous and some, semi-autonomous. As this section will show, some of these institutions have an impact on Holocaust memory, such as the European Institute for Fundamental Rights and the International Holocaust Remembrance Alliance (previously International Task Force for Holocaust Education).

${ }^{78}$ Peter Novick, The Holocaust in American Life, (Mariner Books, 2000). 
Therefore, the EU can be seen to have a more direct and urgent impact on Estonian Holocaust memory, whereas the impact of NATO is indirect, and best represented through bilateral relations with the United States in an attempt to 'smooth' Estonia's transition into NATO.

Leading up to Estonia's accession to NATO and the European Union, the country was placed under great scrutiny by the international community. One aspect of contemporary Estonia which was seen as problematic by both governments, the media and NGOs, relates to collective memory, and how the country represented and had come to terms with the Holocaust as a transnational event as well as with its own participation in it. This topic had not been discussed to a great extent or even seen as an issue by the political elite following re-independence, and it thus came as a surprise. Estonia had never had its 'Jedwabne debate' or Waldheim Affair in the sense that there had been no event that had challenged the nation's victimhood status. There had been minor incidents which brought Estonia's role in the Holocaust to international attention but they had never led to much open and honest discussion amongst the Estonian public through state-directed Vergangenheitsbewaltigung.

Since 1991, little has been published on the Holocaust in comparison with Latvia and Lithuania. The International Commission for the Investigation of Crimes Against Humanity was assembled in 1998 by President Lennart Meri who appointed a number of international diplomats and other experts to serve as members. Interestingly, the date coincided with the beginning of Estonia's entering into talks with NATO and the European Union, and both organisations implied that coming to terms with local collaboration in the Holocaust would be an important step towards accession. The Commission subsequently set out first to examine the period of Nazi occupation of 
1941-1944 before any investigation of the two Soviet occupations. ${ }^{79}$ The Commission was international and comprised diplomats from Denmark, USA, Sweden, Russia and Germany, none of whom were historians, and its sponsored research which was largely 'fact-finding', was delegated to local $\mathrm{PhD}$ and MA historians. This is in contrast to the similar Commission of the Historians of Latvia, whose research was largely directed by expert historians of Latvia as well as scholars of Latvian-Jewish Relations. The commission also was composed of foreign diplomats and NGO representatives, meaning scholarly debate and exchange between both researchers and the commission occurred. The Estonian Commission was largely successful in terms of its fact-finding and produced a huge 1,300 page volume documenting both Soviet and Nazi occupations. However, the volume consists of factual information and nothing more; it is deprived of any kind of analysis or debate, and the findings are not discussed in an international scholarly context. Furthermore, the Commission and its findings did not engage in wider public debate, and the nature of the research shielded it from open scholarly critique and engagement, all of which were undoubtedly inhibited by it being published in English and not in Estonian. It was seemingly set up to 'set things straight' following consistent foreign pressure to do so and did not look to bring about a wider discussion of Estonia's role in the Holocaust in the public or scholarly sphere. ${ }^{80}$ The factual evidence gathered by the Commission was nevertheless extremely important, and has contributed significantly to the historiography of the Holocaust in Estonia.

The USA and its diplomatic agencies frequently indicated that Estonia must do more to engage its citizens in Holocaust education prior to NATO accession in 2004. In

\footnotetext{
${ }^{79}$ Weiss-Wendt, "Why the holocaust does not matter to Estonians," 479-481.

${ }^{80}$ Eva-Clarita Pettai, "Establishing 'Holocaust Memory' - A Comparison of Estonia and Latvia," in Historical Memory Culture in the Enlarged Baltic Sea Region and Its Symptoms Today (Vandenhoeck \& Ruprecht, n.d.), 159-174.
} 
2002, US Deputy Assistant Secretary of State for European and Eurasian Affairs Heather Conley stated that as well as security co-operation, Estonia must focus 'on complex domestic issues like dealing with the history of the Holocaust'. The US Ambassador Joseph DeThomas echoed Conley's statements by criticising how the Holocaust is taught in Estonia and textbooks which 'treat the Holocaust in about oneand-a-half pages'. He recommended that Estonia join the International Task Force for Holocaust Education, an organisation which it applied for in 2002. The US Embassy spent approximately $\$ 2.5$ million in Estonia on educational initiatives relating to the Holocaust between 1994 and 2004 through the Support for Eastern European (SEED) fund.$^{81}$ It is clear also that the European Commission against Racism and Intolerance also held a similar view shortly after accession.

The European Commission against Racism and Intolerance also demonstrated concern at how the Holocaust was discussed and taught in Estonia. In a 2005 study, a report by the Commission stated; "Estonia has yet to examine the full extent of the Holocaust in Estonia and to give it its rightful place in the national debate. Moreover, some electronic media continue to publish anti-Semitic articles with almost complete impunity". 82 The Commission also noted that "the manner in which the Holocaust and the Second Wold War is viewed tends to minimize the gravity of this period in history. Representatives of the Jewish community have thus informed ECRI that many Estonians view the Nazi occupation in a more positive light than the Soviet occupation." recommended that "the Estonian authorities carry out information campaigns about the

\footnotetext{
${ }^{81}$ Stevick, "The Politics of the Holocaust in Estonia: Historical Memory and Social Divisions in Estonian Education," 221-223.

${ }^{82}$ The European Commission against Racism and Intolerance, Third Report on Estonia (Strasbourg, June 24, 2005), 6 .

${ }^{83}$ Ibid., 28.
} 
Holocaust throughout the country in order to ensure that the full gravity of this crime of crimes, its underlying ideology as well as the Nazi ideology are better known. It further recommends that this subject be included in all school curricula". ${ }^{84}$ The Commission, like the US diplomatic agencies discussed above, seem to reflect the same fundamental issue with Estonia's integration into the West; that Holocaust education must implemented as an important factor in its joining, and the importance of coming to terms with the event.

Estonia applied to join the International Holocaust Remembrance Alliance (known as the International Task Force for Holocaust Education until 2013) in 2002, and officially joined in 2007. The IHRA describes itself as an 'intergovernmental body whose purpose is to place political and social leaders' support behind the need for Holocaust education, remembrance, and research both nationally and internationally' and boasts 31 member states. It has been behind several Holocaust museum exhibitions in Estonia. The IHRA's most notable interaction with Estonia is the production of numerous teaching materials for use in schools and teacher-training seminars on Holocaust and human rights education. ${ }^{85}$ The IHRA evolved from the 2000 Stockholm Conference, where a number of heads of state met to discuss the legacy of the Holocaust in the wake of several incidences of Neo-Nazism and Holocaust revisionism. ${ }^{86}$ It was concluded that the international community has a responsibility to come to terms with the Holocaust collectively as a lesson for modern understandings of human rights. The

\footnotetext{
${ }^{84}$ Ibid., 29.

${ }^{85}$ Task Force for International Cooperation on Holocaust Education, Remembrance and Research, "Holocaust Education, Remembrance, and Research in Estonia," accessed March 12, 2013, http://www.holocausttaskforce.org/membercountries/member-estonia.html.

86 "Uncomfortable Questions in Stockholm," BBC, January 26, 2000, sec. Europe, http://news.bbc.co.uk/2/hi/europe/620017.stm.
} 
IHRA also concluded that education was the most useful tool to achieve such a global understanding, and the International Task Force for Holocaust Education was founded shortly thereafter. A similar organisation, which is an autonomous institution of the European Union established in 2007, is the European Agency for Fundamental Rights (FRA), which also seeks to educate and memorialise the Holocaust within the context of modern human rights policies. ${ }^{87}$

International Holocaust Memorial Day was also a product of the Stockholm Conference, and its implementation was encouraged across Europe. The implementation of Holocaust Memorial Day in Estonia in 2003 was clearly seen by the government as more a tool of foreign policy than an act of moral reckoning and an 'entry ticket to NATO'. The Ministry of Education stated that the implementation of the commemorative day in schools would act as "an important foreign policy factor, solidarity with the European and transatlantic community" ${ }^{88}$ It is clear, however, that the Ministry did not view the Holocaust as a subject that should be studied at the expense of atrocities committed by the Soviets against Estonians. Education Minister Mailis Rand issued a memo to all schools, reminding them that all victims of religious, ethnic and political persecution must be remembered on the day commemorating the liberation of Auschwitz-Birkenau. This view was clearly shared by the heads of schools. Many went public with their dissatisfaction and criticism of the national government,

\footnotetext{
${ }^{87}$ Morten Kjaerum, "EUROPA - Agencies and Other EU Bodies - FRA," accessed April 15, 2013, http://europa.eu/agencies/regulatory_agencies_bodies/policy_agencies/fra/index_en.htm.

${ }^{88}$ Doyle Stevick, "The Politics of the Holocaust in Estonia: Historical Memory and Social Divisions in Estonian Education," in Reimagining Civic Education: How Diverse Societies Form Democratic Citizens (Rowman \& Littlefield, 2007), 227.
} 
with several high-profile head teachers stating that the day should not be singled out for the Holocaust but should also include crimes against Estonians. ${ }^{89}$

The Ministry was also defiant of requests from the Simon Wiesenthal Centre ${ }^{90}$. The SWC, which describes itself as a 'global Jewish human rights organisation', 91 suggested it would be more appropriate if Estonia held Holocaust Memorial Day on the $20^{\text {th }}$ of January, to mark the day of the Wannssee Conference as well as when Estonia was declared Judenfrei, or the $7^{\text {th }}$ of August 1942, the date of a massacre of Jews by the $36^{\text {th }}$ Estonian Security Battalion in Novogrudok, Belarus. ${ }^{92}$ The $27^{\text {th }}$ January commemoration clearly 'de-Estonianises' the day and severely reduced the likelihood of Estonians confronting their own role in the Holocaust. Interestingly, the day that International Holocaust Remembrance Day was announced was set at August $6^{\text {th }}$, the day on which Estonia was formally annexed into the Soviet Union in 1940. The backlash from the public was fierce, and according to the SWC, 93\% of Estonians were against the creation of a national memorial day for victims of the Holocaust. ${ }^{93}$ The SWC expressed disappointment that the $27^{\text {th }}$ of January was chosen, instead of a day more closely linked to events in Estonia or symbolic of Estonian participation. Efraim Zuroff, head of the SWCs Israel office, was nevertheless happy with the implementation of

\footnotetext{
${ }^{89}$ Stevick, "The Politics of the Holocaust in Estonia: Historical Memory and Social Divisions in Estonian Education," 228-230.

90 The SWC has been a fairly consistent critic of both the Estonian government and public in terms of how they have dealt with the legacies of local participation in the Holocaust. The SWC is a nongovernmental organisation which boasts a membership of 400,000 families in the USA and is one of the largest Jewish human rights organisations in the world. It frequently interacts with supranational institutions including the UN, UNESCO and the OSCE.

${ }^{91}$ Simon Wiesenthal Centre, "Understand Simon Wiesenthal Center's Mission - Simon Wiesenthal Center," About Us, accessed April 16, 2013, http://www.wiesenthal.com/site/pp.asp?c=lsKWLbPJLnF\&b=4441257\#.UW2r8cp5eQk.

${ }^{92}$ Simon Wiesenthal Center, "Wiesenthal Center Protests Erection of Monument Commemorating Estonian SS-Division Which Fought with Nazis in World War II," The Simon Wiesenthal Center, August 25, 2004, http://www.wiesenthal.com/site/apps/s/content.asp?c=lsKWLbPJLnF\&b=4442915\&ct=5850421\#.UT4M P1d5fRY.

${ }^{93}$ Ibid.
} 
Holocaust Memorial Day and admitted that the policy went against public opinion, which did not support the commemoration. ${ }^{94}$ Zuroff's focus remained on prosecuting suspected Nazi war criminals, stating that focusing only on education would only be sufficient once all living criminals have been brought to justice.

In 2002, Zuroff, who has been described as the SWC's chief 'Nazi hunter', announced the dramatic 'Operation Last Chance', a project which offered financial incentives of up to $\$ 10,000$ for information and evidence that would lead to the conviction of Estonian (as well as Latvian and Lithuanian) Nazi war criminals. Zuroff had previously criticised Estonia for not maximising its efforts to prosecute those complicit in the murder of Jews. Zuroff expressed frustration that following the meetings with both President Lennart Meri and Prime Minister Mart Laar, who both expressed a desire to do more to prosecute Nazi war criminals, nothing was being achieved. $^{95}$

Zuroff’s 2011 book 'Operation Last Chance: One Man’s Quest to Bring Nazi Criminals to Justice ${ }^{96}$ devotes a chapter to Estonia and describes his interactions with the Estonian Government since his first visit in 2001. In the chapter, he issues fairly damning criticism of the Government's attempts to prosecute local Nazi collaborators who participated in the Holocaust and describes the authorities' attitude as 'ambivalent'. He cites the case of Harry Mannil (who died in 2010); an Estonian and suspected former Nazi-collaborator complicit in the murder of Jews who fled to South America. Zuroff

\footnotetext{
${ }^{94}$ Simon Wiesenthal Center, "Wiesenthal Center Nazi-Hunter Urges Estonians to Focus on Their Complicity in Holocaust Crimes on First Official Memorial Day," The Simon Wiesenthal Center, January 27, 2003, http://www.wiesenthal.com/site/apps/s/content.asp?c=lsKWLbPJLnF\&b=4442915\&ct=5853033\#.UT4M K1d5fRY.

95 Ibid.

${ }^{96}$ Efraim Zuroff, Operation Last Chance: One Man's Quest to Bring Nazi Criminals to Justice, Reprint (Palgrave Macmillan, 2011), 121-129.
} 
believes that the Estonian Government's failure to bring Mannil to justice is representative of a country that doesn't treat Holocaust crimes seriously. However, he does not include the plethora of evidence that he claims exists in the book and does not include the perspective of the Estonian Government, who have stated on several occasions why Mannil has not been prosecuted. ${ }^{97}$ Zuroff also makes a rather wild accusation, stating that the Estonian Government have not prosecuted Mannil as he is "one of the richest Estonians in the world", 98 but again, fails to corroborate this with any evidence. It is also likely that Zuroff's unflattering portrayal of Estonia in his book can be partly attributed to the denigration he himself received from the Estonian media and public for his negative comments about the country's attitude toward the Holocaust. He was mocked and attacked on numerous occasions in the media, and describes in his book some fairly distasteful cartoons depicting him in Eesti Ekspress as "the most offensive caricature of me ever published anywhere". 99

Andres Kasekamp, historian and also Director of the Government-funded Estonian Foreign Policy Institute, wrote a fairly strongly-worded article in the Institute's 2005 Yearbook, which criticised Zuroff following mounting pressure by the SWC, ${ }^{100}$ and indeed anyone who had questioned Estonia's commitment to prosecuting Nazi war criminals. Following a brief historical account of the Holocaust in Estonia, Kasekamp stressed that Estonia had worked with the US in relation to educational

97 “Ansip Defends Decision to Close Mannil Probe,” The Baltic Times, January 11, 2006, http://www.baltictimes.com/news/articles/14368/; Andres Kasekamp, "What Really Happened - Estonia and the Holocaust," Valisministeerium, accessed April 15, 2013, http://www.vm.ee/?q=node/8449/3525. ${ }^{98}$ Zuroff, Operation Last Chance, 126.

${ }^{99}$ Ibid., 127.

${ }^{100}$ Events in Estonia which cannot even be seen as directly related to the Holocaust, but more related to Estonian domestic memory politics, have also drawn criticism from Zuroff. He publicly criticised the erection of the Lihula monument, which depicted an Estonian SS Soldier, and noted a worrying trend that Estonian Nazi collaborators were seen as 'heroes'. The Government's relocation of the Bronze Soldier angered the Centre, who stated that it reflected insensitivity to Nazi crimes and noted that it was the Red Army which ended the murder of Jews in Estonia. 
matters and implemented Holocaust Memorial Day. He also presented the work undertaken by the Max Jacobson Commission which researched the Nazi occupation of 1941-1944 before it looked at crimes committed under the Soviet occupation. Kasekamp indicated that many members of the Estonian public were growingly increasingly exasperated by demands, mostly from the SWC, to address issues relating to the Holocaust and "that Soviet war crimes did not seem to be a similar object of attention". 101

The criticisms that have been levelled at Estonia by international actors have taken different approaches which can be conceptualised as 'soft' and 'hard'. Soft approaches are sensitive to the historical trauma suffered in Estonia, and thus see the process of coming to terms with the past as a long-term process best served through education. These approaches have been utilised by state and intergovernmental organisations such as the US Embassy in Estonia as well as the intergovernmental Holocaust education enterprises initiated by the Stockholm conference. Introducing Holocaust education in a broader and more meaningful form in Estonian schools indicates an attempt to inform the next generation of Estonians about the particularities of the Holocaust in Estonia and its meaning in an enlarged Europe, founded upon a principle of human rights with the Holocaust as a foundational myth. The fact that this has been objectionable to many in Estonia, including the Ministry of Education and head teachers of schools, represents the very phenomenon this paper attempts to explain: an international conflict of memory surrounding the Holocaust.

\footnotetext{
${ }^{101}$ Andres Kasekamp, "What Really Happened - Estonia and the Holocaust," Valisministeerium, accessed April 15, 2013, http://www.vm.ee/?q=node/8449/3525.
} 
Hard approaches are much more direct and confrontational and seemingly have no goal other than to bring to international attention cases that indicate Estonian attitudes to the Holocaust. Events such as the Lihula statue incident, the Bronze Solider crisis and the Eesti Ekspress controversy ${ }^{102}$ were all pounced upon by the SWC as being symptomatic of Estonia's attitude towards the Holocaust and insensitivity to Nazi crimes, despite being either not directly related to the Holocaust or small domestic controversies. ${ }^{103}$ Attempts by the SWC to help in the process of bringing Nazi war criminals to justice which have largely failed have also been presented as part of Estonia's contemporary understanding of the Holocaust and failure to come to terms with the past. One area of success for the SWC has been the implementation of Holocaust Memorial Day in Estonia, in which they engaged in an ultimately successful lobbying campaign in an attempt to change the nature of how the Holocaust is remembered in Estonia. Ultimately, the SWC has failed totally to engage Estonian politicians or the public in a meaningful discussion over the Holocaust. Efraim Zuroff's increasingly eccentric accusations and criticisms have continued to draw the wrath of the Estonian public, particularly in responses to online articles, which claim he shows a completely uncritical approach to history. ${ }^{104}$

\footnotetext{
${ }^{102}$ The Eesti Ekspress controversy surrounded the publication of a spoof advert for diet pills in a national newspaper, which used the images of starving Buchenwald death-camp inmates with the caption "One, two, three: Dr Mengele's diet pills work miracles on you," ......"There were no fatties in Buchenwald." ${ }^{103}$ Simon Wiesenthal Center, "Wiesenthal Center Protests Erection of Monument Commemorating Estonian SS-Division Which Fought with Nazis in World War II"; Simon Wiesenthal Center, "Removal by Estonian Government of Soviet-Era Memorial From City Center Reflects Lack of Sensitivity to Nazi Crimes and Insults Their Victims"; Simon Wiesenthal Center, "Wiesenthal Center Denounces 'Sick' Humor Which Insults Holocaust Victims In Leading Estonian News Weekly Eesti Ekspress," The Simon Wiesenthal Center, September 9, 2012, http://www.wiesenthal.com/site/apps/nlnet/content2.aspx?c=lsKWLbPJLnF\&b=4441467\&ct=12179617\# .UT4QDFd5fRY.

${ }^{104}$ Many of the criticisms of Zuroff by Estonians are expressed through crude anti-Semitism, comments which form the basis of Weiss-Wendt's conclusion in 'Why the Holocaust doesn't matter to Estonians'. Weiss-Wendt's wider conclusions which he derives from these incidents remain suspicious; however it is clear that Zuroff's criticism is the subject of fierce rebuttal from many in Estonia.
} 


\section{CHAPTER FIVE: ESTONIAN DOMESTIC HOLOCAUST MEMORY}

\subsection{HOLOCAUST COMMEMORATIONS AND SPEECHES IN ESTONIA}

The intervention from international organisations prompted the Estonian government to act over how the Holocaust was discussed publicly by the state. Estonia faced the profound dilemma of aligning the historical narrative of victimisation, which had dominated since 1991, with the new challenges of their international commitments, which required coming to terms with the Holocaust. The speeches of Estonian political elites can be analysed with this new challenge in mind, and thus the speeches as a communication of elitist constructions of memory should be viewed from the perspective of an international audience.

In 2005, the Estonian state demonstrated a willingness to address the issue of local collaboration through a series of public apologies. Apologies for historical injustice by heads-of-state have been witnessed on several occasions, particularly in relation to local collaboration in the Holocaust; high profile cases included French President Jacques Chirac in 1995 and Polish President Aleksander Kwasniewski in 2001. Both apologies came in a year in which the Republic of Estonia issued an official statement that it "regrets the fact that in cooperation with occupying powers, citizens of the Republic of Estonia also participated in the perpetration of crimes against humanity”. Prime Minister Andrus Ansip followed up the statement with two apologies on $8^{\text {th }}$ May 2005; "I am extremely sorry that this systematic extermination of the Jewish people touches Estonia [..........] I apologise for the fact that Estonian citizens could be found among those who participated in the murdering of people or assisted in the 
perpetration of these crimes". ${ }^{105}$ President Arnold Rüütel also acknowledged and apologised for Estonian citizens who participated at the site of the former Klooga concentration camp:

"Being the President of the Republic of Estonia I feel hurt that among citizens of our state there were those who participated in Nazi crimes. It does not matter whatever motives they had for such behaviour. We condemn these deeds of those people and we apologise for them." 106

The apologies for local participation in the Holocaust can be seen as significant landmarks in Estonia's coming to terms with the past. Both apologies by the politicians, as well as the official state apology, demonstrate 'controlled' statements which have been prepared and thought over and delivered at, and on historically symbolic sites and days. One can speculate that the firestorm of debate that erupted over the Lihula statue in 2004 influenced the Government's decision to apologise in a controlled manner and on its own terms, rather than be forced into a public statement over the representation of the Nazi occupation. The Lihula statue crisis, which contributed to the downfall of Prime Minister Juhan Parts as a result of his 'clumsy handling' of the situation ${ }^{107}$, clearly served as an example to the new Prime Minister Andrus Ansip of the potentially flammable nature of historical public debates in Estonia and the need to issue a clear statement, especially to satisfy the international media and Estonia's Western allies in

\footnotetext{
105 Andrus Ansip, “Address by Prime Minister Andrus Ansip in Klooga, Estonia," Vabariigi Valitsus, May 8, 2005, http://valitsus.ee/en/government/14379/address-by-prime-minister-andrus-ansip-in-klooga,estonia,-8-may-2005.

${ }^{106}$ Arnold Ruutel, "The President of the Republic At the Opening Ceremony of a Memorial to the Victims of the Holocaust That Had Taken Place on the Territory of Estonia During World War II Klooga," The President of the Republic of Estonia, July 24, 2005, http://vp20012006.president.ee/en/duties/speeches.php?gid $=65655$.

${ }^{107}$ Bruggemann and Kasekamp, "The Politics of History and the 'War of Monuments' in Estonia," 432.
} 
order to quash any ambiguity over how the Nazi occupation is portrayed in the public sphere.

Ansip's 'double apology', where he apologised for both the fact that the Holocaust occurred on Estonian soil, and for local participation, represents a clear attempt to come to terms with Holocaust within a European memory framework. The speech is delivered on May $8^{\text {th }}$, which is a day of mourning in Estonia as the date marks the beginning of the second Soviet occupation. The day has a quite different meaning in many European countries however, and is a victorious commemoration marking the victory over Nazism. The apologies thus represent a certain adherence to Europe's 'foundational myth' understanding of the Holocaust, given that Ansip was willing to accept and apologise for Estonian complicity in Nazi crimes on such a historically sensitive date for the Estonian public. Rüütel's apology, which was on International Holocaust Memorial Day, also demonstrates a willingness to address Estonian guilt within an international memory context. Being delivered on the site of the former Klooga concentration camp and on the date of the liberation of Auschwitz, the speech and apology bridges this international understanding of the Holocaust as a transnational event, with the particularities of the event on Estonian soil. Ultimately, both speeches can be seen as attempts by the Estonian political elite to integrate Estonia into the broader, Europeanised Holocaust memory narrative. This is demonstrated by a readiness to minimise their own narrative of victimhood, and recognise their duties upon joining the Western community; that the issue of the Holocaust must be addressed.

Clearly, however, the Estonian state was not prepared to apologise without mentioning the crimes of the Soviet Union against Estonians. The reminder or mentioning of Soviet crimes toward Estonians during a discussion of the Holocaust is 
done either by specifically referring to the Soviet Union or by discussing the Holocaust under the umbrella of 'totalitarian crimes and occupation', which, in a discussion about Nazi occupation, effectively acts as a euphemism for Soviet crimes. President Rüütel, when discussing what the Holocaust means in modern Estonia noted; "as long as there are those who wish to justify or even praise the crimes committed during both German as well as Soviet occupation, there is a danger that such deeds could be repeated", ${ }^{108}$ Similarly, at another speech in Israel, Rüütel said:

"We remember our past and we tell our children about it, not only on the Holocaust Memorial Day, January $27^{\text {th }}$. Neither should we forget the crimes committed by the Soviet regime, the victims of which were Estonians, Jews, as well as people from other nationalities". 109

Andrus Ansip, on Holocaust Memorial Day in 2012, stated that "the crimes of totalitarian regimes are indelible and can never be justified". ${ }^{110} \mathrm{He}$ also said in 2005 , "The system of states and relations of nations built in Europe has no place for Nazism or any other totalitarian ideas". ${ }^{111}$ Holocaust Memory Day in 2007 saw Ansip deliver his strongest condemnation of totalitarian crimes during a discussion of the Holocaust; "Estonia too suffered during and after the Second World War under totalitarian

\footnotetext{
${ }^{108}$ Ruutel, "The President of the Republic At the Opening Ceremony of a Memorial to the Victims of the Holocaust That Had Taken Place on the Territory of Estonia During World War II Klooga."

${ }^{109}$ Arnold Ruutel, "The President of the Republic At the State Dinner in Honour of the President of the State of Israel, H.E. Mr Moshe Katsav, Kadriorg Palace," The President of the Republic of Estonia, September 19, 2005, http://vp2001-2006.president.ee/en/duties/speeches.php?gid=68724.

${ }^{110}$ Andrus Ansip, "Prime Minister Andrus Ansip's Speech at the Opening of the Memorial to the Estonian Jews Who Died in the Holocaust, the Memory Gallery, at the Estonian Jewish Community Centre," Vabariigi Valitsus, January 27, 2012, http://valitsus.ee/en/government/prime-minister-andministers/andrus-ansip/speeches/53272/prime-minister-andrus-ansip\%E2\%80\%99s-speech-at-theopening-of-the-memorial-to-the-estonian-jews-who-died-in-the-holocaust,-the-memory-gallery,-at-theestonian-jewish-community-centre.

${ }^{111}$ Ansip, "Address by Prime Minister Andrus Ansip in Klooga, Estonia."
} 
regimes and we paid for this with our independence. Their crimes will never expire and their perpetrators cannot be justified. "112

Condemnations of Soviet crimes occur frequently in speeches of Estonian politicians at a range of public events and commemorations. However, by doing it during a speech dealing with the Holocaust, often on Holocaust Memorial Day, a clear message is being sent regarding the role of the Holocaust in Estonian memory: that it cannot be discussed without a reminder of the barbarity shown toward Estonians during the periods before and after the Holocaust. Given that International Holocaust Day is a global event, it sends a clear message to the international community of the historical consequences of the Second World War in Estonia, and that the historical trauma suffered by Estonians must be discussed within the context of 'totalitarian crimes'. Could this be defined as 'comparative trivialisation'? ${ }^{113}$ By discussing the crimes of the Soviet Union within this context, this trend within the speeches could be perceived as an attempt to downplay the uniqueness of the Holocaust as a historical event. However, it is clearly not intended to act as any kind of comparison, but rather to address both the crimes of the Soviets and Nazis under one definitional framework, both of which are demonstrated as equally important to the Estonian state. A clear deduction one can make from the discussion of Soviet crimes, is its self-defensive nature. It doesn't explicitly look to exonerate those who participated in crimes against humanity. However, it does look to place the Estonians who participated in the Holocaust's actions within the context of fear experienced by many in the immediate aftermath of the first

\footnotetext{
${ }^{112}$ Andrus Ansip, "Statement by Prime Minister Andrus Ansip on International Holocaust Remembrance Day," Vabariigi Valitsus, January 27, 2007, http://valitsus.ee/en/government/13665/statement-by-primeminister-andrus-ansip-on-international-holocaust-remembrance-day.

${ }^{113}$ Shafir, Between Denial and "Comparative Trivialization."
} 
Soviet occupation and the willingness to deliver retribution which were undoubtedly present at the time.

As opposed to the apologies seen, the discussion of Soviet crimes demonstrates a reversal back into the national memory narrative of victimhood, and away from addressing Estonian participation in the Holocaust. By referring to the 'totalitarian regimes' of the Second World War, both Soviet and Nazi crimes are presented as undistinguishable from one another. This issue can also be found in the broader 'East vs. West' memory conflict in Europe which has emerged since the accession of postCommunist East-European states to the EU and represents an attempt by Estonian politicians, to place themselves firmly in the 'East' camp, and push for a greater recognition of Soviet crimes by Western Europe.

Another self-defensive action that can be found in the speeches is the promotion and reminder of positive Estonian-Jewish relations during the interwar period. President Arnold Rüütel at the opening of the Klooga concentration camp memorial in 2005 discussed the Holocaust as an interruption of strong Estonian-Jewish relations characteristic of the interwar period. Rüütel said "The Nazis executed the Jews who had stayed in Estonia; those victims were people who had been residents and citizens of Estonian Republic where the rights of ethnic minorities were respected". ${ }^{114}$ Rüutel also demonstrated in September 2005 at a speech in Israel, that Estonia had taken in Jews from anti-Semitic Europe and Russia, and that the cultural autonomy of the Jewish community in Estonia proclaimed in 1926 was brutally ended by the Soviet Union. ${ }^{115}$ In 2010, Foreign Minister Urmas Paet, speaking at a memorial to 'convoy number 73',

\footnotetext{
${ }^{114}$ Ruutel, "The President of the Republic At the Opening Ceremony of a Memorial to the Victims of the Holocaust That Had Taken Place on the Territory of Estonia During World War II Klooga."

${ }^{115}$ Ruutel, "The President of the Republic At the State Dinner in Honour of the President of the State of Israel, H.E. Mr Moshe Katsav, Kadriorg Palace."
} 
in which 300 French Jews were deported to the Klooga concentration camp, looked to demonstrate Estonia's superiority in regards to local Jewish relations during the interwar period: "Just a few years before, two different democracies had met destruction - old and flourishing France, and young but nevertheless developing Estonia which had promised cultural autonomy to Jewish people". ${ }^{116}$ Paet went into more detail on Holocaust Memorial Day in 2011, noting that "in June 1926 Estonia was the first country in the world where Jews could proclaim their cultural autonomy". 117 President Toomas Hendrik Ilves' speech at a dinner in Israel in 2010 documented various contributions the Jewish community had made in Estonia throughout history and how Estonian-Jewish relations have been flourishing ever since re-independence. "It is no accident that Estonia was the first country in the world where Jews could proclaim their cultural autonomy [....] That is why Estonia has the honour of being included in the Jews' Golden Book". 118 Another direct reference to Jewish cultural autonomy during the interwar period can be found in the speech by Prime Minister Andrus Ansip on Holocaust Memorial Day 2012 at the opening of the memorial to the Estonian Jews who died in the Holocaust. ${ }^{119}$

This trend does not fall into either the Estonian narrative of victimisation, nor does it represent an acceptance of any kind of global Holocaust memory. Rather, it speaks to the specific dynamics of Estonian-Jewish relations and the role of Jews as an

\footnotetext{
${ }^{116}$ Urmas Paet, "Estonia Has Freedom to Commemorate and Obligation to Remember All Victims of the Holocaust," Valisministeerium, June 6, 2010, http://www.vm.ee/?q=en/node/9546.

${ }^{117}$ Urmas Paet, "In Remembering Holocaust, We Emphasise Unique Value of Every Single Life," Valisministeerium, January 27, 2011, http://www.vm.ee/?q=en/node/10675.

${ }^{118}$ Toomas Hendrik Ilves, "Address of the President of the Republic at the Official Dinner in Honour of Shimon Peres, President of the State of Israel, in Jerusalem," President of Estonia, June 28, 2010, http://www.president.ee/en/official-duties/speeches/2709-address-of-the-president-of-the-republic-at-theofficial-dinner-in-honour-of-shimon-peres-president-of-the-state-of-israel-in-jerusalem/index.html.

${ }^{119}$ Ansip, "Prime Minister Andrus Ansip's Speech at the Opening of the Memorial to the Estonian Jews Who Died in the Holocaust, the Memory Gallery, at the Estonian Jewish Community Centre."
} 
'internal positive other ${ }^{120}$ in Estonian identity. By defining Estonia's historical identity as progressive, liberal and friendly to ethnic minorities, politicians can be seen as an attempting to legitimise the 'Europeanness' of Estonians against the Russian 'other'. The Russian other in this sense is represented negatively in two ways; either by showing that the Jews of Estonia had fled from anti-Semitic oppressors to the liberal-European Estonia, and also that these progressive laws and attitudes in Estonia were only ended due to the Soviet occupation.

The purpose or utility of mentioning the positive interwar relations between Estonians and Jews as well as progressive attitudes by the Estonian state towards Jews, particularly on Holocaust Memorial Day, remains difficult to pin down. Weiss-Wendt locates a relevant problem with this trend when he states that the consistent references to the 'benevolent' attitude that Estonian's held towards Jews and their lack of antiSemitism "obscures rather than helps to explain the reasons why some Estonians decided to collaborate in the Nazi mass murder of Jews". ${ }^{121}$ However, the reminder can be seen as an attempt to distance Estonia from its neighbours where the Nazi occupation harnessed widespread anti-Semitism to encourage locals to participate in the mass murder of Jews. By removing itself from the East European context, more room is given for the particularities of the Holocaust in Estonia, where there were no pogroms and anti-Semitism was not as pre-disposed in Estonian society. It therefore refrains from exonerating local participants in the crimes, but also demonstrates resistance to the idea that Estonia should be lumped into the 'East European' context (something which is often done by the Simon Wiesenthal Centre by their absurd labelling of Estonia as a 'perpetrator state') and is sensitive to the particularities of the Holocaust in Estonia.

\footnotetext{
${ }^{120}$ Petersoo, "Reconsidering Otherness," 121.

${ }^{121}$ Weiss-Wendt, "Why the Holocaust Does Not Matter to Estonians," 2008, 492-493.
} 
There is a further attempt to utilise the Estonian-Jewish memory dynamic during political speeches, demonstrated by the attempt to construct a 'collective victim' myth which looks to create historical similarities between Estonians and Jews as a threatened ethnic group or between the Estonian Republic and the State of Israel. The most lucid example of this trend can be found in Andrus Ansip's 2012 speech: "I understand and share your grief and pain caused to your community by the Holocaust [...] as a small nation, Estonians have always understood the suffering of the Jews and held their friendship dear". ${ }^{122}$ Ilves at the opening of the Tallinn Synagogue in 2007, states: “Among alien corn or under foreign powers, we both - Estonians and Jews - have hung on to our language, our culture, our customs, in order to shape them finally into a country of our own". ${ }^{123}$ In a speech in Israel in 2010, Ilves also makes several references to historical similarities between Estonians and Jews: "For Estonians, too, the dream of our own state is sacred and inviolable; no one has ever managed to force us to give up that dream [..... Our paths are intertwined, and we share a similar historical experience." Interestingly, Ilves also looks to privately link himself to the Jewish struggle: "I, too, was born far from my homeland and dreamed of returning to my ancestral home in Viljandi County. I know what it feels like to be cut off from your homeland". ${ }^{124}$ President Arnold Rüütel creates similarities between Estonia and Israel in a more indirect fashion: "Both our countries became independent in the last century. The Estonian state was established when there was no state of Israel yet. The State of Israel was established when occupied Estonia could not recognise it. But it clearly

\footnotetext{
${ }^{122}$ Ansip, "Prime Minister Andrus Ansip's Speech at the Opening of the Memorial to the Estonian Jews Who Died in the Holocaust, the Memory Gallery, at the Estonian Jewish Community Centre."

${ }^{123}$ Toomas Hendrik Ilves, "President of the Republic at the Opening of the Jewish Synagogue, 16 May 2007," President of Estonia, May 16, 2007, http://www.president.ee/en/official-duties/speeches/2579president-of-the-republic-at-the-opening-of-the-jewish-synagogue-16-may-2007/index.html.

${ }^{24}$ Ilves, "Address of the President of the Republic at the Official Dinner in Honour of Shimon Peres, President of the State of Israel, in Jerusalem."
} 
showed Estonians that independence is possible even in extremely complicated conditions. $" 125$

This trend, like the mentioning of progressive Estonian attitudes towards Jews during the interwar period, seeks to side-step the issue of the Holocaust in Estonia by offering Jews the role of a 'positive internal other'. Also like the mentioning of positive interwar relations between Jews and Estonians, the purpose of the collective victimhood myth reflects an attempt to draw the international community's attention to the historical particularities of Estonia. Whilst there are clearly significant problems in comparing the Jewish struggle to the plight of Estonians, attempts to do so demonstrate a willingness to present to the international community, which may not be aware of Estonian history, the sufferings endured within an understandable context. The fact that this trend can mostly be seen at diplomatic events between Israel and Estonia is also notable. It can therefore also be viewed as a way of promoting strong bilateral relations between Estonia and Israel, a key partner of NATO.

Speeches at commemorative events thus represent an attempt by the Estonian political elite to demonstrate a willingness to come to terms with the Holocaust whilst maintaining Estonia's victimhood status, as well as reminding the international community of the historical accuracies which are important in understanding Estonia's attitude toward the Holocaust. Apologies have been a common way for politicians acting on behalf of their states to show the world that the nation is aware and addressing the issue of participation in the Holocaust. The apologies witnessed in Estonia show an open willingness to right past wrongs. They come with a condition however: that the

\footnotetext{
${ }^{125}$ Ruutel, "The President of the Republic At the State Dinner in Honour of the President of the State of Israel, H.E. Mr Moshe Katsav, Kadriorg Palace."
} 
historical traumas and particularities of Estonian history be respected and understood. There is a clear willingness to remove Estonia from the East-Central European context where the Holocaust occurred in a different manner, which explains the differences in contemporary memory of the Holocaust. This is most likely deemed necessary, as the Holocaust in Estonia is frequently discussed within the general East-Central European context without much precision in terms of the historical particularities regarding how the Holocaust was conducted. The speeches all followed the Lihula statue crisis, which ignited public debate in Estonia in a way that was often deemed unsavoury in the Western press and led to many worries over a revival of Nazism. It is clear that the Government does not wish for historical debates to spiral out of control in such a manner, and has, to an extent, looked to set things straight primarily for an international audience. The use of positive historical Estonian-Jewish relations and the 'collective victimhood' myth both effectively serve as distractions from addressing Estonia's role in the Holocaust and its memory as a transnational event. They are designed seemingly to address issues that are more urgent to the Estonian state; to engage in tight bilateral relations with strong Western powers and legitimise their own European integration.

\subsection{ESTONIAN MUSEUMS AND THE HOLOCAUST ${ }^{126}$}

The speeches of Estonian political elites represent a direct, top-down communication of a politically constructed memory narrative. Museums represent a different phenomenon. Whilst they are top-down and constructed, much lies in the symbolism in the displays, hidden meanings in the content and also the choices utilised

\footnotetext{
${ }^{126}$ The analysis of museums is entirely based on the author's own observations during visits to the museums, unless otherwise stated and referenced.
} 
by curators. Burch and Zander argue "that museums shape national history and collective memory - thereby justifying present as well as articulating the past-means that they are both valued and value-laden sites". ${ }^{127}$ Velmet adds to this by describing the three Baltic Museums of Occupation as "attempts at writing the final chapter for the national narrative of their respective countries. Though purportedly academic institutions of critical inquiry, museums are also discursive establishments, conduits of power transmitting and shaping narratives of national identity through their scholarly and political authority". 128

Whilst the Estonian History Museum is a state-museum, both the Museum of Occupations and the Jewish Museum cannot be seen as directly under the influence of the government. Whilst the government contributes two-thirds of the finance for the Museum of Occupations and sought its construction, the museum is operated and run by a private organisation, meaning that its representations can be seen as driven by both the Government and the operating organisation. The Jewish Museum is not funded by the state and operated privately; however, the Gallery of Memory memorial was entirely funded by the Estonian government, thus complicating the picture of how representative these two museums are of state narrative construction. The museums are thus best analysed in terms of their continuities with the state narratives seen in the speech analysis, as well as the secondary source analysis which demonstrates a trend of Estonian victimhood in national memory.

An appropriate place to begin is the official state museum: the Estonian History Museum. Whilst it contains very little information on the Holocaust or World War II, it

\footnotetext{
${ }^{127}$ S. and Ulf, "Preoccupied by the Past The Case of Estonian's Museum of Occupations," 55.

${ }^{128}$ Velmet, “Occupied Identities," 190.
} 
is nevertheless worthy of a brief analysis as it best represents the state narrative of Estonian history displayed in a museum. The Museum is located in the heart of Tallinn's Old Town in the medieval Great Guild Hall, a Hanseatic building which has been a thriving centre of economic and cultural activity for centuries. The permanent exhibition is given the title 'Spirit of Survival' and seeks to present 11,000 years of Estonian history, beginning from the first settlers right up until Estonian reindependence in 1991. The exhibit gives an extremely broad overview of the Estonian people and nation, and mainly focuses on their interaction with and rule by foreigners. The overriding message is that the ten different occupations Estonians have been ruled by over centuries have had a dangerous and negative impact on the native population. Nevertheless, the indefatigable Estonians have struggled throughout and maintained their language, culture and customs despite attempts to supress them, particularly through Germanisation and Russification. They are ultimately 'survivors'. One key aspect of the museum is the attempt to view Estonians as a Nordic and European people, and that Russification was largely unsuccessful as it is completely alien to Estonians. Thus, the overriding narrative of the museum looks to offer a triumphant picture of Estonian history, that the Estonian state has historical roots which stretch back thousands of years, and that foreign rule has failed in eliminating or even, to an extent, disrupting Estonian culture. The Estonians are portrayed as victims, but victims who have ultimately prevailed.

Analysing the museum in a stricter framework, using Pille Petersoo's typology of Estonian identity, ${ }^{129}$ one can conclude that the museum largely agrees with her analysis. Russia is discussed through negative and menacing terms in the museum,

\footnotetext{
${ }^{129}$ Pille Petersoo, "Reconsidering Otherness: Constructing Estonian Identity*," Nations and Nationalism 13, no. 1 (2007): 117-133.
} 
giving Russia the role of an 'external negative other'. The emphasis on both Estonia's 'Nordicness' and 'Europeanness' as well as the beneficial historical, cultural and economic influences these cultures have had on Estonia also validates Petersoo's claim, that Estonians see both Europe, Scandinavia and Finland as 'external positive others'. The Baltic German's are also given positive and negative roles; they were oppressive land barons, and reduced Estonians to a peasant-like status, however, they also provided cultural, economic and linguistic benefits for the nation. Interestingly, the museum does not discuss the role of Russians in contemporary Estonia, meaning Petersoo's claim that Russians are also 'internal negative others' is indeterminable, although this absence in itself could indicate that Russians are not viewed entirely favourably in the context of contemporary Estonian identity.

The majority of the Museum displays are dedicated to the middle-ages, and promotes Estonia's history as a thriving hub of Baltic trade. In one room, which shows how various wars have affected Estonia, the Second World War is discussed in a brief passage. The brutal first Soviet occupation is discussed before a brief mention of the German occupation. Estonian support for the Nazi occupation is described as 'lukewarm' as opposed to being totally against the Soviet occupation. Throughout the entire museum, no mention is made of the Holocaust on Estonian soil with the exception of a brief snapshot of the entrance to Klooga concentration camp on a video display. Clearly, this relatively small museum does not look to give nuanced accounts of Estonian history but rather provide broad overviews for foreign visitors. It is therefore not surprising that the complexities of the Second World War, important as they are, are not discussed in any detail. However, what the museum does show is the over-riding themes which are contextually important for understanding the nuances; first, Estonia is 
a nation with deep historical roots within Northern Europe and the Baltic Sea Region. Second, Estonia has been the victim of many foreign occupations and repressions throughout its history, the most negative being the Baltic German dominance, the Russian Empire and the Soviet Union, but against all odds, has maintained its culture, language and traditions. The most prominent state museum in Estonia thus paints a triumphant and in many ways positive picture of Estonian history, whilst also maintaining a narrative of victimhood. This is in contrast to the partly state-funded, but privately operated Museum of Occupations, which is more relevant to this study of Estonian Holocaust memory.

The Okupatsioonide Muuseum (Museum of Occupations) in Tallinn was established in 1998 by Olga Kristler-Ritso at the request of the Estonian government. ${ }^{130}$ Kristler-Ritso is an expatriate of Estonia who fled the Second World War to the United States and is head of the Kristler-Ritso Foundation which oversees the long-term development of the museum, while its day-to-day operations are administered by Executive Director Heiki Ahonen (until 2012). Approximately 25,000 visitors per year are welcomed at the museum, many of whom are international tourists. Whilst ticket sales account for a third of the revenue generated, the rest is funded by the Estonian state via the Ministry of Culture, which in 2009, amounted to approximately $€ 190,000 .{ }^{131}$ The Museum cites as its main objective to:

"Document the catastrophes and cataclysms, which took place during the last fifty years and to find detailed proof about the past based on facts and analysis. We are interested in how the generation which re-established Estonia's independence in 1991 was formed and want to learn which obstacles they had to

\footnotetext{
130 "Stanford Takes Estonia's 'Museum of Occupations' Under Its Wing," September 21, 2011, http://news.stanford.edu/news/2011/september/library-estonia-museum-092111.html.

${ }^{131}$ Aro Velmet, "Occupied Identities: National Narratives in Baltic Museums of Occupations," Journal of Baltic Studies 42, no. 2 (2011): 190-191.
} 
overcome. We are interested in the life of Estonians, and also of Russians, Germans, Jews, Swedes and other minorities under the totalitarian regime of the second half of the $X X^{132}$ century. We have no reason to be ashamed of our history, rather the reverse. At the same time we should not forget our experiences and keep silent. On the contrary, we must prevent the dreadful offences from being forgotten. ",133

The museum sits just outside Tallinn's Old Town, and a mere $300 \mathrm{~m}$ from the Estonian Parliament (Riigikogu). The short walk down the hill from the Riigikogu to the museum is symbolic in itself, and contains monuments and memorials dedicated to Estonian independence including a stone etched with "20. VIII 1991". There are also busts of Rear Admiral John Pitka (1872-1944), who founded the Defence League which fought successfully in the independence war, and Major General Orasmaa (1890-1943), leader of the Home Guard, who was arrested by the Soviets in 1940 and died in captivity. ${ }^{134}$ The Museum itself is housed in a modern, twisted-looking building made predominantly of glass supported by concrete.

Upon entering the museum, the visitor is at first confronted by souvenirs and books, largely dedicated to Estonian occupation and independence. The short books offered as history guides offered in several different languages at the beginning of the museum route mark the first formal attempt to educate the visitor about Estonia's plight between 1939 and 1991. They are written by Mart Laar, a historian and prominent politician who has been Prime Minister on two occasions since 1991. The short guides are categorised into four booklets: Red Terror: Repressions of Soviet Occupation

\footnotetext{
${ }^{132}$ This is actually incorrect, as both occupations began in the first half of the $20^{\text {th }}$ Century.

${ }^{133}$ Okupatsioonide Muuseum, "Museum of Occupations: Who We Are," Okupatsioonide Muuseum, accessed March 11, 2013, http://okupatsioon.ee/en/who-we-are.

${ }^{134}$ S. and Ulf, "Preoccupied by the Past The Case of Estonian's Museum of Occupations," 59-60.
} 
Authorities in Estonia, Estonia in World War II, The Forgotten War: 1944-1956 and A Birds Eye View of Estonian History.

Three out of the four guides focus heavily on the negative role of the Soviet Union in Estonia, particularly during the first occupation of 1940-1941. The guide dedicated to Estonia's experiences in World War II devotes a single section to Nazi occupation. The Holocaust is dealt with in one short paragraph, which gives a brief overview of the plight of Estonian and European Jews on Estonian soil during the German occupation. One statement in the guide which can be seen as misleading is the sentence "Nazis did not succeed in instigating Estonians to exterminate other ethnic groups or carry out pogroms", ${ }^{135}$ Given that the museum guide, written in English, is for visitors who more than likely do not hold expertise in Estonian history, the sentence may appear to absolve Estonia of any guilt whatsoever of complicity in the Holocaust. The guide also confusingly states, after implying that Estonians were not collaborators in the Holocaust, that the Nazi occupation "does not release those citizens of the Estonian Republic who fulfilled orders of the Nazis, of liability for the crimes committed. But it cannot be the Estonian state or people who are to bear responsibility". ${ }^{136}$ The paragraph devoted to the Holocaust also includes the peaceful relations between Estonians and Jews during the interwar period, and mentions the Estonians who rescued the few Jews who did survive. It is striking that in a section devoted to the history of the Nazi occupation, one of the most brutal and shocking aspects, and what many would see as the defining aspect of the Second World War in Europe [The Holocaust], is confined to a paragraph, with half of it devoted to a cautious stance around the issue Estonian complicity. The two quotes above demonstrate an

\footnotetext{
${ }^{135}$ Mart Laar, Estonia In World War II (2005), 25.

${ }^{136}$ Ibid., 25
} 
unclear public presentation of Estonia's role in the Holocaust and to what extent collaborators should be held responsible. The first misleading statement can be chalked up to poor translation or writing; however, it does represent certain confusion over the nature of Estonian collaboration.

The visual display of the museum, with bland, grey walls and ceiling, looks to recreate the totalitarian atmosphere of the Soviet Union and place the visitor inside a prison, similar to the many KGB prisons located around Estonia which are now museums aimed at both shocking and informing foreign visitors. The scattered props, which are mainly suitcases and Soviet memorabilia, aim to present the tragedy of the deportations of Estonians and the loss of Estonian way of life. The display which focuses on the Nazi occupation, unavoidably, can only be observed in comparison to both Soviet occupations. The objects on display include Nazi administration documents ordering the execution of Estonians as well as a 28 minute rolling video. The video, which provides a short documentary of the Nazi occupation, demonstrates that the Soviet occupation was indeed far more brutal on local Estonians than the German occupation. It shows German troops being greeted as liberators, and scenes of jubilation as Nazi troops take control of Tallinn. Soviet terror and brutality is discussed by locals in graphic detail, which looks to serve as a basis for explaining Estonian civilian and military collaboration with Nazis and the Waffen SS, where several veterans are taped to tell of their motives. At some moments, the video even tries to 'sell' the Nazi occupation to the viewer; the Nazis promised Estonians autonomy and the possibility of a 'Greater Estonia' and most importantly, protection from the brutal Soviets. The film also discusses the West's betrayal of Estonia at the Tehran conference where it was agreed that 1941 borders would be maintained in the event of an Allied victory. 
Estonians are shown fighting valiantly alongside the Nazis in 1944 in an attempt to prevent a second occupation. Estonia declared independence following the Nazi retreat which lasted for two days, before the Red Army crushed any hope of Estonian selfdetermination. The solemn end to the film is when the Holocaust is finally discussed in anecdotal form, with locals recalling the smell of burning flesh and grim scenes upon finding corpses in the concentration and labour camps. The fact that the Holocaust is displayed as an afterthought to the entirety of the Nazi occupation is extremely telling, particularly given the intense focus the short movie has on legitimising and explaining Estonian-Nazi cooperation.

The remainder of the Museum is devoted entirely to the decades-long post-war Soviet occupation. Historical agency is provided to Estonians; consistent with contemporary Estonian historiography on the Soviet years, and the eventual fall of the USSR is represented in its jubilant entirety. During the time of the author's visit, there were two temporary displays devoted to Estonian 'forest brothers': the Estonian bandits who fled to the forests to resist Soviet occupation in the 1950s. Another particularly poignant display was the 'letters in bark' exhibition, which showed the human tragedy of Soviet deportations through the words written on bark sent home by Baltic prisoners in Siberia. The downstairs area contains decrepit and mutilated Soviet statues, monuments which have been ripped out of their prominent settings in central Tallinn and repositioned to the dingy downstairs basement.

In sum, the Holocaust is largely absent from the museum both in terms of a full factual presentation of the nature of the Holocaust within Estonia and any display which shows the suffering of Estonian and European Jews as a negative aspect of Nazi occupation. In the Museum, despite its own central mission statement and claim to be 
"interested in the life of Estonians, and also of Russians, Germans, Jews, Swedes and other minorities under the totalitarian regime of the second half of the XX century", victimhood status is preserved solely for the Estonian state and people in the context of both Soviet and Nazi occupations. When the Holocaust is discussed, one of the 25,000 visitors who visit the Museum each year, be it a foreign tourist or indeed anyone not historically inquisitive, is more than likely to be misled about the nature of the Holocaust in Estonia in terms of local collaboration. The historical guide written by Mart Laar is particularly troubling in terms of presenting a historically and morally accurate picture of how and why Estonia was the setting for the destruction of Jewish life in Estonia and the murder of nearly 10,000 Jews from across Europe. The Holocaust is discussed within the context of Soviet and Nazi totalitarianism which looks to externalise guilt to either the Nazis, whose orders the locals were following, or the Soviets, who terrorised the Estonians to such a degree that they could not be held responsible for collaborating. The trend of highlighting Estonia's progressive attitudes toward the Jewish minority, also found in the speeches of elites, is also present in the museum guide, the only detailed educational resource within the museum.

The Jewish Community Centre which houses the Estonian-Jewish Museum and Gallery of Memory is located on Karu Street, approximately one kilometre outside the Old Town. It is situated beside the brand new \$2 million Synagogue, which opened in 2007. The Synagogue received international attention, as it was the first to be constructed in Estonia since the Second World War (the original was built in 1883, but destroyed in a Soviet air raid in 1944). ${ }^{137}$ Estonian President Toomas Hendrik Ilves,

\footnotetext{
137 "First Post-World War Two Synagogue Opened in Tallinn, Estonia," European Jewish Congress, accessed April 15, 2013, http://www.eurojewcong.org/estonia/831-first-post-world-war-two-synagogueopened-in-tallinn-estonia.html.
} 
accompanied by Israeli President Shimon Peres, marked the occasion with a speech praising Estonian-Jewish relations by saying "Estonia has been a good and safe home for the Jewish People"138 and highlighting Estonia's progressive attitudes toward the Jews during the 1920s. It is in this small hub of Jewish life, in the corridor of the third floor of the modest community centre building, that the Gallery of Memory can be found. The Gallery of Memory shows two glass tablets, both fractured in two, displaying the names of the 947 Estonian Jews who perished in Estonia during the Nazi Occupation, their dates of birth and a Star of David next to each name. Also displayed are plaques which commemorate the 1942 Wannsee Conference where the Final Solution was discussed and Estonia was declared 'Judenfrei'. The two Estonians, Professor Uku and Eha Masing, who were given the 'Righteous Among the Nations' Medal by the state of Israel, are also commemorated. A plaque thanks the donors of the Gallery of Memory project, which includes the Government of Estonia, the American Jewish Joint Distribution Committee, two prominent private donors, the Estonian Jewish Museum (which is funded entirely by private donors) and a list of 33 other individuals.

The pamphlet offered at the Gallery of Memory and upon entrance to the Estonian Jewish Museum is 34 pages long. On the front a map of Estonia which has been stamped 'Judenfrei' with the title 'The Holocaust on the Territory of NaziOccupied Estonia 1941-1944' (the pamphlets are available in Estonian, Russian and German). The introduction titled 'Blot on the Map' describes the publication as " $a$ brief guide to the details associated with the national tragedy of the Jewish population on a tiny corner of Estonian land" and that "One should not expect revelations and

\footnotetext{
${ }^{138}$ Ilves, "President of the Republic at the Opening of the Jewish Synagogue, 16 May 2007."
} 
sensations from our story. One shouldn't anticipate zealous accusations. We simply attempt to follow the history and background of the Holocaust in Estonian lands. But even that is enough". ${ }^{139}$ The pamphlet summarises in a brief but nuanced fashion: the history of Jews in Estonia, the initial stages of Nazi occupation where Estonian Jews were eradicated, the import and murder of European Jews, life in the concentration and labour camps, and a map displaying all sites where Estonian and European Jews were killed as well as the locations of concentration camps. It does not shy away from discussing local collaboration, and includes information regarding the crimes of the Omakaitse, the $287^{\text {th }}$ Police Battalion which consisted of Estonians and the Estonian SS Division. $^{140}$

The pamphlet devotes a section to memory of the Holocaust ${ }^{141}$, including the ruthless retribution against and prosecution of Nazi collaborators under the Soviet Union occupation as well as a discussion of the suppression of Holocaust memory during the Soviet Occupation. It contains a list of memorials located around Estonia at the former sites of execution dedicated to the Holocaust. The pamphlet engages with much recent scholarship on the Holocaust in Estonia, and weaves the findings of the History Commission with those of scholars such as Gurin-Loov, Elhonen and Maripuu. Anton Weiss-Wendt, author of Murder without Hatred: Estonians and the Holocaust (2009) is also credited with a contribution to the history of the Holocaust in Estonia despite the controversial nature of his book.

The modest Jewish Museum is situated in one room attended by one member of the staff. The Museum displays (in Estonian and Russian language only) the history of

\footnotetext{
${ }^{139}$ Josef Katz, The Holocaust on the Territory of Nazi-occupied Estonia, 1941-1944 (Tallinn: Jewish Community of Estonia Publication, 2012), 4.

${ }^{140}$ Ibid., 8-23.

${ }^{141}$ Ibid., 24-28.
} 
Jews in Estonia. It devotes a considerable section to the Holocaust in Estonia, with a few objects seized from Estonian Jews as well as detailed pictures, maps, tables and text documenting the history of the Holocaust on Estonian territory delivered in a similar style to the pamphlet. The rest of the museum focuses on Jewish life from the $19^{\text {th }}$ century to the present day, including prominent Estonian Jews and the activities of the Jewish community today.

The overall theme of both the Gallery of Memory and the Jewish Museum is a willingness to portray the plight of Estonian Jews during the Nazi occupation in a realistic manner backed up by scholarly research from prominent Estonian historians of the Holocaust. The displays and museum focus more on the Estonian Jews and less on the majority of Jews who died in Estonia during the Holocaust who came from outside national borders, demonstrating a reluctance to view the Holocaust in Estonia as part of a transnational genocide, in favour of portraying it as a national tragedy and 'blip' in the otherwise solid Estonian-Jewish relations which are presented in national history. The location of the museum and memorial are also telling; located outside the centre of Tallinn next to the Synagogue, on the third floor of the Jewish Community Centre, the museum is not given the prominence of other Museums or memorials such as the Museum of Occupations is located away from the grandiose 'independence' sites of memory of central Tallinn. If museums are thus representative of memory, the Jewish Museum is offered the part of an outsider. The Government's role in the opening of the Synagogue, where President Ilves stated that "Estonia has been a good and safe home for the Jewish People" in front of the President and Chief Rabbi of Israel, can be looked back upon as ironic, given that the building located 50m away from him as he spoke 
would become the place in which the 'uncomfortable' history of Estonian collaboration in the Holocaust would be presented to anyone who cared to visit. 


\section{CONCLUSiON}

This thesis has attempted to explore how political memory is impacted by both international and domestic forces through an analysis of Holocaust memory in Estonia. By drawing on theories utilised by Lebow, Langenbacher and Müller, memory was defined as political elite-based public memory attempting to construct a narrative of history in order to fulfil a political purpose. In the case of Estonia and the Holocaust, the political purposes looking to be fulfilled which are evident in the analysis are an attempt to both recognise the trauma of the Holocaust as a transnational event in order to meet the demands of integration into Europe and also maintain Estonia's victimhood status which dominates the domestic memory narrative. Thus the political elite have the task of both addressing the issue of Estonian participation in the Holocaust, which renders themselves 'victimisers' while also maintaining their status as 'victims' under the brutal and long Soviet occupation.

The Holocaust in Estonia had not been given substantive attention by politicians, the public or even scholars, until the nation's accession to NATO and the EU in 2004. This can be explained in part by the very nature of the Holocaust; the Jewish community was small, and the thus did not have the same interaction with Estonians as other, larger Jewish communities in East-Central Europe had with their respective ethnic majorities. The Holocaust was conducted in labour camps far away from Estonian public life, and there were no pogroms. Thus the Holocaust, despite occurring on Estonian soil, did not feature much in the minds of the public during or even following the event itself and goes some way in explaining why there is no strong collective memory of the event itself. During the period of Soviet occupation, the Holocaust was not discussed outside a hegemonic, centralised narrative imposed by 
Moscow. Even upon re-independence, the Holocaust had not been a topic discussed a great deal in scholarly, public or political spheres until formal negotiations to join NATO and the EU began, sparking a period of 'Westernisation'.

The country was subsequently placed in the spotlight by the Western international community, and was surprised to find itself the target of criticism from several Jewish organisations, most notably the Simon Wiesenthal Centre, particularly over its failure to prosecute Estonian collaborators suspected of war crimes. Following US pressure, Estonia looked to address the Holocaust in a more direct fashion and in coordination with European educational groups. They joined the International Task Force for Holocaust Education, a transnational Holocaust education organisation, and implemented national Holocaust Memorial Day in 2003, to be held annually on January $27^{\text {th }}$. Holocaust Memorial Day was not popular among the Estonian public and even less so among some elite politicians. The Simon Wiesenthal Centre went so far as to claim that $93 \%$ of Estonians were against such a day. The impetus to discuss and come to terms with the Holocaust thus came from outside its borders, something that is demonstrative of a world where collective memory, along with economics, politics and culture is becoming increasingly globalised.

The Estonian political elite have also looked to address the Holocaust publicly through speeches and commemorations. Leading representatives of the Estonian state face the fundamental dilemma of reconciling the nation's victim status with the Holocaust, where some Estonians were not victims, but perpetrators. The most salient theme within speeches of political elites when discussing the Holocaust is a willingness to highlight Soviet barbarity toward the Estonians in an attempt to explain and contextualise the motives of local collaborators. Politicians have also reminded the 
international community of Estonia's relatively good record of cordial inter-war relations between Estonians and Jews. Political elites, more often than not during diplomatic ceremonies with Israel, can also be seen to draw historical comparisons between Estonians and Jews as a threatened and victimised ethnic group. There have been two apologies for local collaboration, both in 2005, by President Arnold Rüütel and Prime Minister Andrus Ansip, demonstrating a certain willingness to come to terms with the Holocaust through an admission to a certain level of Estonian complicity. The speeches thus tell us the Estonian state is prepared to accept guilt, but only if other nations respect and educate themselves on Estonia's fairly unique history with respect to local collaboration, positive inter-war relations and the brutality of Soviet crimes. This is something which can be easily placed into the context of supranational memory politics, and the on-going memory conflict between 'East and West'. The speeches, in themselves are educational, and whilst it might seem inappropriate to some to condemn Soviet crimes on Holocaust Memorial Day, this is a reflection of the state's willingness to bring the plight of Estonians and indeed many former Communist nations who suffered trauma to international attention. The attempts to draw historical comparisons between the plight of Jewry and Estonians can be seen as unconventional and problematic, however it again reflects an attempt to educate the world on how Estonians have got to where they have today, and that their trauma is as important as anyone else's.

The museums of Estonia, which reflect other top-down, sculpted and constructed versions of history have also been analysed in an attempt to discover how the Holocaust is portrayed in conjunction with Estonia's traumatic Soviet past. The Estonian History Museum, which is a state museum, presents Estonians as historical 
victims by focusing on the numerous occupations over centuries. However, the message is triumphant, and demonstrates that despite centuries of oppression, Estonia is now a thriving, modern, European independent state. This message does not directly relate to the Holocaust; however it provides an indication that viewing an event where Estonians were not victims could be problematic. The Museum of Occupations in Tallinn, popular amongst both tourists and the public alike, is particularly silent on the Holocaust. In fact, one has to go to the third floor of the modest Jewish Community Centre, where the Estonian Jewish Museum and 'Gallery of Memory' memorial is located, for any instructive information regarding the fate of both Estonian and European Jews during the Second World War. The conflict of memory between Estonia's international commitments and domestic memory narrative was not found in such a profound sense in the Museum of Occupations, which did not look to engage in a serious debate or educational initiative regarding the Holocaust. The much smaller Jewish Museum however looked to engage the visitor in a difficult but nevertheless important attempt to come to terms with the past, typified by its open discussion of local collaboration. Thus, if museums are representative of elitist historical narratives and are actively constructed lieux de memoire, the Museum of Occupations suggest that the Holocaust is something peripheral to Estonian trauma and should be discussed after crimes committed against Estonians have been established in a 'hierarchy of victimisation'. This is despite the Museum's central claim to present the plight of all ethnic groups as equal, including Jews. The location and content of the Holocaust Museum suggest that the Holocaust in the modern day is an issue for the small ethnic-Jewish community in Estonia, and is not presented as something in conflict with the dominant Estonian victimhood narrative. 
Estonians, quite rightly, define themselves by their national history and in particular the tragedies that befell the small nation during the second half of the twentieth century. However, an important aspect of Estonian history and perhaps the defining moment of European history has been overlooked in the process. The Estonian Government's approach towards the Holocaust can be seen as broadly targeted towards education and a long-term process, rather than something to be imposed on the population. The outcomes of this tactic can only be realised in a generation. However, until then, it seems that coming to terms with the Holocaust will continue to be something on the periphery of the Estonian national agenda. There also appears to be a fundamental fracture between Western Europe's view of the Holocaust, which is often perceived as too hegemonic, and Eastern Europe's traumatic past, which only ended two decades ago. The Prague Declaration can be seen as a landmark moment in terms of addressing this fracture. However, until its fruits can be gathered, it seems to have led to an institutionalisation of the dispute rather than to any kind of consensus.

What does the future hold for Estonian perceptions of the Holocaust? Whilst it would be foolish to make predictions, the flammable nature of Geschichtspolitik in Estonia is well-documented and well-known, particularly by the political establishment. It is therefore likely to be a continuation of the current pragmatic approach to dealing with the Holocaust within the context of Soviet crimes. However, this does not mean to imply that tensions over the issue couldn't erupt in a manner similar to the other 'wars of memories'. As an example, Anton-Weiss Wendt's book 'Murder without Hatred' was the subject of fierce criticism from many in the public and scholarly spheres for its unsavoury and controversial conclusions, demonstrating that a lingering sensitivity to change in the dominant historical narrative of victimhood remains prevalent. Clearly, 
accusations of the 'Estonian fascist revival' which were voiced without restraint throughout the Soviet occupation continues to be strong in the memory of many, something which is only exacerbated by the Russian Federation's similar charges and antagonisms. Thus the nature of Holocaust memory is overwhelmingly a Soviet-induced legacy, and implies that 'coming to terms with the past' will only occur once the still palpable tension of occupation dies out. 


\section{BIBLIOGRAPHY}

\section{PRIMARY SOURCES}

Ansip, Andrus. "Address by Prime Minister Andrus Ansip in Klooga, Estonia." Vabariigi Valitsus, $\quad$ May 2005. http://valitsus.ee/en/government/14379/address-by-prime-minister-andrus-ansipin-klooga,-estonia,-8-may-2005.

“Prime Minister Andrus Ansip's Speech at the Opening of the Memorial to the Estonian Jews Who Died in the Holocaust, the Memory Gallery, at the Estonian Jewish Community Centre.” Vabariigi Valitsus, January 27, 2012. http://valitsus.ee/en/government/prime-minister-and-ministers/andrusansip/speeches/53272/prime-minister-andrus-ansip\%E2\%80\%99s-speech-at-theopening-of-the-memorial-to-the-estonian-jews-who-died-in-the-holocaust,-thememory-gallery,-at-the-estonian-jewish-community-centre.

"Statement by Prime Minister Andrus Ansip on International Holocaust Remembrance Day." Vabariigi Valitsus, January 27, 2007. http://valitsus.ee/en/government/13665/statement-by-prime-minister-andrusansip-on-international-holocaust-remembrance-day.

The European Commission against Racism and Intolerance. Third Report on Estonia. Strasbourg, June 24, 2005.

European Parliament. "European Parliament Resolution of 2 April 2009 on European Conscience and Totalitarianism," April 2, 2009. http://www.europarl.europa.eu/sides/getDoc.do?pubRef=-//EP//TEXT+TA+P6TA-2009-0213+0+DOC+XML+V0//EN\&language=EN

Ilves, Toomas Hendrik. "Address of the President of the Republic at the Official Dinner in Honour of Shimon Peres, President of the State of Israel, in Jerusalem." President of Estonia, June 28, 2010. http://www.president.ee/en/officialduties/speeches/2709-address-of-the-president-of-the-republic-at-the-officialdinner-in-honour-of-shimon-peres-president-of-the-state-of-israel-injerusalem/index.html.

. "President of the Republic at the Opening of the Jewish Synagogue, 16 May 2007." President of Estonia, May 16, 2007. http://www.president.ee/en/officialduties/speeches/2579-president-of-the-republic-at-the-opening-of-the-jewishsynagogue-16-may-2007/index.html.

Kasekamp, Andres. "What Really Happened - Estonia and the Holocaust." Valisministeerium. Accessed April 15, 2013. http://www.vm.ee/?q=node/8449/3525.

Katz, Josef. The Holocaust on the Territory of Nazi-occupied Estonia, 1941-1944. Tallinn: Jewish Community of Estonia Publication, 2012. 
Kjaerum, Morten. "EUROPA - Agencies and Other EU Bodies - FRA.” Accessed April 15 , 2013. http://europa.eu/agencies/regulatory_agencies_bodies/policy_agencies/fra/index _en.htm.

Laar, Mart. Estonia In World War II.

Okupatsioonide Muuseum. "Museum of Occupations: Who We Are." Okupatsioonide Muuseum. Accessed March 11, 2013. http://okupatsioon.ee/en/who-we-are.

Paet, Urmas. "Estonia Has Freedom to Commemorate and Obligation to Remember All Victims of the Holocaust." Valisministeerium, June 6, 2010. http://www.vm.ee/?q=en/node/9546.

—. "In Remembering Holocaust, We Emphasise Unique Value of Every Single Life." Valisministeerium, January 2011. http://www.vm.ee/?q=en/node/10675.

Ruutel, Arnold. "The President of the Republic At the Opening Ceremony of a Memorial to the Victims of the Holocaust That Had Taken Place on the Territory of Estonia During World War II Klooga." The President of the Republic of Estonia, July 24, $2005 . \quad \mathrm{http}: / / \mathrm{vp} 2001-$ 2006.president.ee/en/duties/speeches.php?gid=65655.

. "The President of the Republic At the State Dinner in Honour of the President of the State of Israel, H.E. Mr Moshe Katsav, Kadriorg Palace." The President of the Republic of Estonia, September 19, 2005. http://vp20012006.president.ee/en/duties/speeches.php?gid=68724.

Simon Wiesenthal Center. "Removal by Estonian Government of Soviet-Era Memorial From City Center Reflects Lack of Sensitivity to Nazi Crimes and Insults Their Victims." The Simon Wiesenthal Center, April 30, 2007. http://www.wiesenthal.com/site/apps/s/content.asp?c=lsKWLbPJLnF\&b=44429 $15 \& c t=5852151 \#$.UT4RbVd5fRY.

. "Wiesenthal Center Denounces 'Sick' Humor Which Insults Holocaust Victims In Leading Estonian News Weekly Eesti Ekspress." The Simon Wiesenthal Center, September 9, 2012. http://www.wiesenthal.com/site/apps/nlnet/content2.aspx?c=lsKWLbPJLnF\&b= 4441467\&ct=12179617\#.UT4QDFd5fRY.

"Wiesenthal Center Protests Erection of Monument Commemorating Estonian SS-Division Which Fought with Nazis in World War II." The Simon Wiesenthal Center, August 25, 2004. http://www.wiesenthal.com/site/apps/s/content.asp?c=lsKWLbPJLnF\&b=44429 $15 \& c t=5850421 \#$.UT4MP1d5fRY.

. "Understand Simon Wiesenthal Center's Mission - Simon Wiesenthal Center." $\begin{array}{lllll}\text { About Us. Accessed } & \text { April }\end{array}$ http://www.wiesenthal.com/site/pp.asp?c=lsKWLbPJLnF\&b=4441257\#.UW2r8 cp5eQk 


\section{SECONDARY SOURCES}

“Ansip Defends Decision to Close Mannil Probe.” The Baltic Times, January 11, 2006. http://www.baltictimes.com/news/articles/14368/.

Assmann, Aleida. "Transformations Between History and Memory." Social Research 75, no. 1 (Spring 2008): 49-72,354.

Assmann, Jan, and John Czaplicka. "Collective Memory and Cultural Identity." New German Critique no. 65 (April 1, 1995): 125-133.

Birn, Ruth Bettina. "Collaboration with Nazi Germany in Eastern Europe: The Case of the Estonian Security Police." Contemporary European History 10, no. 02 (2001): 181-198.

Blutinger, Jeffrey. "An Inconvenient Past: Post-Communist Holocaust Memorialization." Shofar: An Interdisciplinary Journal of Jewish Studies 29, no. 1 (2010): 73-94.

Bruggemann, Karsten, and Andres Kasekamp. "The Politics of History and the "War of Monuments' in Estonia.” Nationalities Papers 36, no. 3 (July 2008): 425-448.

Cecile Felicia Stokholm Banke. "Remembering Europe's Heart of Darkness: Legacies of the Holocaust in Post-war European Societies." In A European Memory? Contested Histories and Politics of Remembrance, by Małgorzata Pakier and Bo Stråth, 163-174. Contemporary European History 6. Oxford: Berghahn Books, 2010 .

Challand, Benoît. "1989, Contested Memories and the Shifting Cognitive Maps of Europe." European Journal of Social Theory 12, no. 3 (August 1, 2009): 397408.

Diner, Dan. "Restitution and Memory: The Holocaust in European Political Cultures." New German Critique no. 90 (2003): 36.

"EU Shuns Law on Communist Crimes." BBC, December 22, 2010, sec. Europe. http://www.bbc.co.uk/news/world-europe-12059475.

"First Post-World War Two Synagogue Opened in Tallinn, Estonia." European Jewish Congress. Accessed April 15, 2013. http://www.eurojewcong.org/estonia/831first-post-world-war-two-synagogue-opened-in-tallinn-estonia.html.

Gross, Jan T. Neighbors: The Destruction of the Jewish Community in Jedwabne, Poland. Penguin Books, 2002.

Hackmann, Jörg. "From National Victims to Transnational Bystanders? The Changing Commemoration of World War II in Central and Eastern Europe." Constellations 16, no. 1 (2009): 167-181. 
Halbwachs, Maurice. On Collective Memory. Translated by Lewis A. Coser. 1st ed. University Of Chicago Press, 1992.

Joesalu, Kirsti. "The Role of the Soviet Past in the Memory Politics Through Examples of Speeches from Estonian Presidents." Europe-Asia Studies 64, no. 6 (August 1, 2012).

Judt, Tony. "The Past Is Another Country: Myth and Memory in Postwar Europe." Daedalus 121, no. 4 (October 1, 1992): 83-118.

Langenbacher, Eric. "Twenty-first Century Memory Regimes in Germany and Poland An Analysis of Elite Discourses and Public Opinion." German Politics \& Society 26, no. 4 (Winter 2008): 50-81.

Langenbacher, Eric, and Yossi Shain, eds. Power and the Past: Collective Memory and International Relations. Georgetown University Press, 2010.

Lebow, Richard Ned, Wulf Kansteiner, and Claudio Fogu, eds. The Politics of Memory in Postwar Europe. Duke University Press Books, 2006.

Levy, Daniel, and Natan Sznaider. Holocaust And Memory In The Global Age. Translated by Assenka Oksiloff. 1st ed. Temple University Press, 2005.

Mälksoo, Maria. "The Memory Politics of Becoming European: The East European Subalterns and the Collective Memory of Europe." European Journal of International Relations 15, no. 4 (2009): 653-680.

Mertelsmann, Olaf. "Mõrv Ilma Vihata. Eestlased Ja Holokaust." Sirp: Eesti Kultuurileht, October 23, 2009. http://www.sirp.ee/index.php?option=com_content\&view=article\&id=9589\&cat $\mathrm{id}=9 \&$ Itemid $=13 \&$ issue $=3422$.

Müller, Jan-Werner. Memory and Power in Post-War Europe: Studies in the Presence of the Past. Cambridge University Press, 2002.

"Narvast Pärit Ajaloolane: Eestlastel Puudub Inimlikkus.” Ekspress. Accessed April 22, 2013. http://www.ekspress.ee/news/paevauudised/ajalugu/narvast-paritajaloolane-eestlastel-puudub-inimlikkus.d?id=28787571.

"New German President Faces Touch of Apprehension in Israel." The Times of Israel. Accessed April 17, 2013. http://www.timesofisrael.com/new-german-presidentcriticized-for-equating-nazism-with-communism/.

Nora, Pierre. "Between Memory and History: Les Lieux de Mémoire." Representations no. 26 (April 1989): 7-24.

Olick, Jeffrey K. "Collective Memory: The Two Cultures." Sociological Theory 17, no. 3 (November 1, 1999): 333-348.

Onken, Eva-Clarita. "The Baltic States and Moscow's 9 May Commemoration: Analysing Memory Politics in Europe." Europe-Asia Studies 59, no. 1 (2007): 23-46. 
Novick, Peter. The Holocaust in American Life. None. Mariner Books, 2000.

Paabo, Heiko. "War of Memories: Explaining 'Memorials War' in Estonia." Baltic Security and Defence Review 10 (2008): 5-28.

Petersoo, Pille. "Reconsidering Otherness: Constructing Estonian Identity*." Nations and Nationalism 13, no. 1 (2007): 117-133.

Pettai, Eva-Clarita. "Establishing 'Holocaust Memory' - A Comparison of Estonia and Latvia." In Historical Memory Culture in the Enlarged Baltic Sea Region and Its Symptoms Today, 159-174. Vandenhoeck \& Ruprecht, n.d.

Phillips, Leigh. "EU Rejects Eastern States' Call to Outlaw Denial of Crimes by Communist Regimes." The Guardian, December 21, 2010, sec. World news. http://www.guardian.co.uk/world/2010/dec/21/european-commissioncommunist-crimes-nazism.

"Russia Condemns Estonian SS Legion Reunion - 1." RIA Novosti. Accessed May 21, 2013. http://en.rian.ru/russia/20070730/69960232.html.

S., Burch, and Zander Ulf. "Preoccupied by the Past The Case of Estonian's Museum of Occupations." Scandia 74, no. 2 (2008): 53-73.

Shafir, Michael. Between Denial and "Comparative Trivialization": Holocaust Negationism in Post-communist East Central Europe. Hebrew University of Jerusalem, Vidal Sassoon International Center for the Study of Antisemitism, 2002.

Snyder, Timothy. "Memory of Sovereignty and Sovereignty over Memory: Poland, Lithuania and Ukraine, 1939-1999." In Memory and Power in Post-War Europe: Studies in the Presence of the Past, 39-58. edited by Jan-Werner Müller. Cambridge University Press, 2002.

"Stanford Takes Estonia's 'Museum of Occupations' Under Its Wing," September 21, 2011. http://news.stanford.edu/news/2011/september/library-estonia-museum092111.html.

Stevick, Doyle. "The Politics of the Holocaust in Estonia: Historical Memory and Social Divisions in Estonian Education.” In Reimagining Civic Education: How Diverse Societies Form Democratic Citizens, 217-243. Rowman \& Littlefield, 2007.

Stevick, E. Doyle. "Education Policy as Normative Discourse and Negotiated Meanings: Engaging the Holocaust in Estonia." PROSPECTS 40, no. 2 (June 1, 2010): 239-256.

Tamm, Marek. "History as Cultural Memory: Mnemohistory and the Construction of the Estonian Nation." Journal of Baltic Studies 39 (2008): 499-516.

"Uncomfortable Questions in Stockholm." $B B C$, January 26, 2000, sec. Europe. http://news.bbc.co.uk/2/hi/europe/620017.stm. 
Velmet, Aro. "Occupied Identities: National Narratives in Baltic Museums of Occupations." Journal of Baltic Studies 42, no. 2 (2011): 189-211.

Weiss-Wendt, Anton. Murder Without Hatred: Estonians and the Holocaust. 1st ed. Religion, Theology, and the Holocaust. Syracuse, N.Y: Syracuse University Press, 2009.

. "Why the Holocaust Does Not Matter to Estonians." Journal of Baltic Studies 39, no. 4 (2008): 475-497.

Zuroff, Efraim. Operation Last Chance: One Man's Quest to Bring Nazi Criminals to Justice. Reprint. Palgrave Macmillan, 2011. 